\title{
'URF DAN PEMBENTUKAN HUKUM ISLAM MENURUT AL-SHÂTIBÎ
}

\author{
Oleh: \\ Mansur \\ STAI Miftahul Ulum Pamekasan \\ elcmansur@yahoo.co.id
}

\begin{abstract}
:
Al-Shâthibî dividing habit at two kinds of 1) al-shar'iyyah al-'awâid, that is expressed habit expressly by nash shar'î 2) al-nâs bain al-jâriyyah al'awâid, habit that happened in one society community and of shara' silent do not comment. Nonetheless, shara' also legalizeing it. In meaning, law even also follow what habit will desire. Al-Shâtibî also divide evaluated habit from its its at two kinds of 1) al-'âmmah al'awâid, habit going into effect public, do not change in all room, situation and time 2) Different habit along with friction of room, situation and time. Term this 'âdah by al-Shât\}ibî given on to word 'ibâdah. Because of religious service basically is total compliance and adherence to Allah, hence 'âdah basically is more emphasizing its. But so, al-Shât\}ibî giving exemption that habits which in it there are adherence, hence its application have to bow under nash. Implementation 'urf al-Shâtibîat practical plain in the effort forming of Islam law only going into effect at deed which do not contain adherence. In the meaning that more orienting habit at relation pattern between human being is delivered to habit going into effect. On that account, law even also will be interconnected follow change of habit.
\end{abstract}

Key Words: 'Urf, Hukum Islam, Al-Shâtibî

\section{A. Pendahulan}

Sebagai Khalîfah Allâh fi al-Ardh', manusia menjadi mandataris Allah untuk mengelola jagat alam raya ini. Demi untuk akselerasi

\footnotetext{
${ }^{1}$ QS. Al-Baqarah [2], 30. Manusia disebut oleh al-Qurân dengan istilah bashar dan insân. Manusia dalam posisinya sebagai bashar lebih berdimensi lahiriyah yang memiliki bawaan kodrati untuk menjalankan fungsi 'abd (penghambaan kepada Allâh SWT) dengan segala bentuk ketundukan, kepatuhan dan keterikatan pada tanggung jawab. Sebagai insân yang lebih berorientasi ruhaniyah, manusia mempunyai akal untuk dipermanfaatkan menjalankan fungsi khalifah yang memiliki kebebasan berbuat dan berkreasi. Realisasi dari fungsi 'abd adalah berakidah dan beribadah, sedangkan fungsi khalifah adalah menciptakan kebudayaan/peradaban. Lihat, M.A. Fattah Santoso, Agama dan Keragaman Kebudayaan, Perspektif Peradaban Islam, dalam Zakiyuddin Baidhowi 
pencapaian misi risalah tersebut, agama Islam datang dengan menyeru mengajak manusia untuk mengenali dan sudi menggunakan jalan-jalan keselamatan yang termaktub dalam kitab sucinya, Al-Qurân ${ }^{2}$. Mengenali tak cukup hanya dengan membaca secara tekstual, tapi lebih mengarah pada pembacaan secara kontekstual guna menjadikannya sebagai welstanchauung. Untuk mencapai idealisme tersebut, Al-Qurân seolah selalu menantang dirinya untuk dibedah, karena Al-Qurân akan bermakna jika berada dalam konteks ruang dan waktu manusia. Mencari titik temu dan relevansi antara teks Al-Qurân dan konteks masyarakat menjadi tugas berat yang diemban oleh para ulama (baca, mufassir). Hal ini disebabkan, karena Al-Qurân sudah diyakini sebagai kitab suci yang universal (berlaku untuk setiap ruang dan waktu manusia) yang dianugerahkan oleh Allah SWT kepada seluruh umat manusia. Universalitas Al-Qurân terletak pada cakupan pesannya yang menjangkau pada seluruh lapisan umat manusia, kapan saja dan di mana saja. ${ }^{3}$

Pembacaan secara komprehensip terhadap sebuah teks ajaran, baik Al-Qurân maupun al-Hadîth, menjadi tanggung jawab manusia sebagai khalîfah di muka bumi. Oleh sebab mandat khalîfah merupakan amanat yang di dalamnya mengandung hak, kewajiban dan tanggung jawab. Inilah hakikat taklîf (pembebanan) kepada manusia yang berada di bawah satu bangunan yang kokoh. Bangunan ini yang menjadi rumah tempat berteduh bagi manusia yang mencari jati dirinya, memberikan perlindungan keselamatan dan mendorong tumbuhnya kesejahteraan yang utuh bagi

dan Mutohharun Jinan (ed.), Agama dan Pluralitas Budaya Lokal, (Surakarta: Pusat Studi Budaya dan Perubahan Sosial UM Surakarta, 2003), hlm. 47.

2 'Abd al-Wahhâb Khallâf mendefinisikan Al-Qurân adalah Kalâmullâh yang dibawa oleh al-Rûh al-Amîn (Jibrîl) pada kalbu Muh\}ammad Ibn 'Abdullâh sebagai Rasulullah, memakai redaksi bahasa Arab dengan lautan maknanya yang sangat dalam. Tujuannya adalah sebagai hujjah atas kerasulan Muhammad. Selain itu juga berfungsi sebagai perundang-undangan bagi manusia yang bisa dicari petunjuknya dan merupakan satu bentuk ibadah bagi orang yang membacanya. Al-Qurân dikodifikasi dengan dua belah mushaf yang diawali dengan surat al-Fâtihah dan diakhiri dengan surat al-Nâs, yang dinukil secara mutawâtir dari generasi ke generasi, baik berupa tulisan maupun bacaannya serta terpelihara dari segala perubahan. Lihat, 'Abd al-Wahhâb Khallâf, 'Ilm Ushûl al-Fiqh, (Kuwait : Dâr al-Qalam, 1987), hlm. 23.

${ }^{3}$ M.H. Thabâthabâ'î menjelaskan bahwa keuniversalan Al-Qurân terbukti karena tidak hanya mengkhususkan pembahasannya kepada umat Islam semata, tetapi juga berbicara kepada umat non-muslim, yaitu orang-orang kâfir, mushrik, Yahûdî dan Nashrânî. Lihat, M. H. Thabâthabâ'î, Mengungkap Rahasia Al-Quran, (Bandung : Mizan, 1987), hlm. 33.

$358 \mid$ JURNAL LISAN AL-HAL 
kemanusiaan. Bangunan itu tiada lain adalah Hukum Islam ${ }^{4}$. Dan upaya untuk mengenal dan menghayati tujuan dibentuknya bangunan tersebut dikenal dalam bahasa Al-Qurân dengan tafaqquh fî al-dîn (memahami agama) ${ }^{5}$.

Redaksi tafaqquh inilah yang kemudian melahirkan istilah fiqh, yang berarti pemahaman ${ }^{6}$. Pemahaman disini lebih mengarah pada penguasaan seluruh ajaran keagamaan, yang meliputi persoalan-persoalan sosial-kemasyarakatan, hukum-hukum praktis-amali, teologi, etika dan sebagainya7. Sehingga, seorang faqîh menjadi sangat terpuji karena memahami dan menguasai ajaran agama secara mendalam dan komprehensip ${ }^{8}$. Hanya saja, fiqh yang pada dasarnya mencakup keseluruhan pemahaman terhadap teks ajaran, dalam perkembangannya telah mengalami reduksi makna yang cukup drastis yang secara serta merta telah diarahkan pada pemahaman hukum praktis-amali. Maka

\footnotetext{
4 Secara garis besar, hukum Islam dapat dirinci dalam tiga hal. Pertama, petunjuk dan bimbingan untuik memperoleh pengenalan yang benar tentang Allah SWT dan alam gaib. Hal ini disebut dengan al-Ah\}kâm al-Shar'iyyah al-I'tiqâdiyyah yang menjadi bidang kajian ilmu Kalâm atau Tauhid. Kedua, petunjuk dan ketentuan-ketentuan untuk pengembangan potensi kebaikan yang ada dalam diri manusia, supaya dia menjadi makhluk yang terhormat dan beradab. Hal ini disebut dengan al-Ahkâm al-Shar'iyyah alKhuluqiyyah yang merupakan focus kajian ilmu Tashawwuf atau Akhlaq. Ketiga, ketentuan-ketentaun dan seperangkat peraturan untuk menata hubungan keseharian yang bersifat amaliyah praktis, baik hubungan tersebut bersifat vertikal (habl min Allâh) maupun horizontal (habl min al-Nâs) untuk menjamin tegaknya keadilan dan terwujudnya ketentraman dalam pergaulan sosial kemasyarakatan. Hal ini dinamakan al-Ahkâm al-Shar'iyyah al-'Amaliyyah yang menjadi bidang garapan ilmu Fiqh. Lihat, 'Abd al-Wahhâb Khallâf, ibid, hlm. 32.

${ }^{5}$ Hal itu diungkapkan dalam QS. Al-Taubah [9], 122:

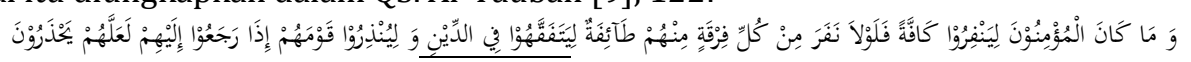

“Tidak sepatutnya bagi orang-orang mukmin semuanya pergi (ke medan perang). Mengapa tidak pergi dari tiap-tiap golongan di antara mereka beberapa orang untuk memperdalam pengetahuan mereka di bidang agama dan untuk untuk memberi peringatan kepada kaumnya jika mereka mereka sudah kembali kepadanya, supaya mereka dapat menjaga dirinya".

${ }^{6}$ Abû Fadhl Jamâluddîn Muhammad bin Mukarram ibn Manzhur, Lisân al-'Arab, Vol. XIII, (Beirut : Dâr al-Fikr, tt), hlm. 522.

7 'Abd. Al-Wahhâb Ibrâhîm Abû Sulaimân, al-Fikr al-Ushûlî, Dirâsah Tahlîliyyah Naqdiyyah, (Jeddah : Dâr al-Shurûq, 1984), hlm. 20.

${ }^{8}$ Hadîth ini diriwayatkan oleh al-Turmudhî, yaitu

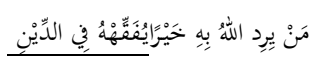

"Barang siapa yang diinginkan oleh Allah menjadi yang terbaik, maka ia akan dijadikan sebagai orang yang menguasai agama secara mendalam" Lihat, Abû 'Îsâ Muhammad ibn 'Îsâ ibn Saurah, Sunan al-Turmudhî, Vol. IV, (Beirut : Dâr al-Fikr, 1994), hlm. 294. 
kedudukan seseorang lebih ditentukan sejauh mana dia menguasai ajaran agama dalam bidang hukum (baca, ilmu fiqh). Mereka yang berkecimpung mendalami aspek-aspek intelektual agama adalah para hakim, bukan teolog. Hal mana lebih disebabkan oleh disiplin ilmu yang 'dianggap' paling tinggi adalah yurisprudensi (baca, fiqh/hukum). Dengan kata lain, Islam lebih menekankan ortopraksis dari pada ortodoksi ${ }^{9}$. Sehingga, fiqh dijadikan sebagai rancang-bangun konstitusi dalam Islam.

Fiqh, sejatinya, tidak hanya memuat detail-detail hukumnya. Melainkan juga mengandung prinsip-prinsip umum yang melatarinya. Oleh karenanya, fiqh juga mengandung ide besar yang bertumpukan pada al-mas\}lah\}ah al-'âmmah (kemaslahatan umum) dan 'urf (adat-kebiasaan), yang senantiasa mengalami perubahan di sepanjang denyut nadi zaman ${ }^{10}$.

9 Pengedepanan bidang hukum ketimbang bidang-bidang lainnya (teologi dan etika) dalam Islam lebih disebabkan pada perkembangan awal Islam. Bahwa Islam muncul di daerah Arab, dimana sistem hukum yang dipunyai oleh suku-suku Arab yang nomaden sedang mengalami kemunduran. Oleh sebab itu, sejak masa hijrah kaum muslim awal bertanggung jawab terhadap persoalan-persoalan politik masyarakat. Sebagai akibatnya, aturan-aturan dalam al-Quran lebih berkenaan dengan persoalanpersoalan praksis yang terjadi dan pada akhirnya menjadi sistem hukum yang lengkap, baik yang berkenaan dengan persoalan privat maupun publik sebagai penjelasan baik praktik keagamaan. Bahkan ragam permasalahan baru di daerah-daerah taklukan Islam pasca wafatnya Nabi menuntut penyelesaian dengan legalitas keagamaan. Karena Islam lahir sebagai agama dan Negara, maka sangat wajar jika persoalan sosial keagamaan yang bersifat praktis lebih banyak muncul ke permukaan dari pada persoalan yang bersifat teologis. Lain halnya dengan kaum Kristiani, yang lebih menekankan pada ranah teologi. Karena sejak awal dia hidup di lingkungan kerajaan Romawi yang mempunyai sistem hukum yang telah berjalan efektif dan selama 300 tahun, dalam perkembangan agama Kristen tidak mengalami gejolak politik yang berarti. Lihat, William Montgomery Watt, Islam, terj. Imron Rosjadi, (Yogyakarta: Jendela, 2002), 103-104. bandingkan dengan MA. Sahal Mahfudh, Wajah Baru Fiqh Pesantren, (Jakarta: Citra Pustaka, 2004), xxii

${ }^{10}$ Al-Nadawî menyajikan sebuah adagium fiqh :

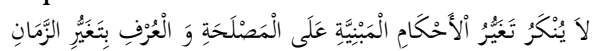

"Tidak dapat diingkari, bahwa hukum yang didasarkan pada kemaslahatan dan 'urf/adat akan berubah sesuai dengan perubahan zaman". Lihat, 'Alî Ahmad al-Nadawî, al-Qawâ'id al-Fiqhiyyât; Mafhûmuhâ wa Nash-atuhâ wa Tathawwuruhâ wa Dirâsât Muallifâtihâ wa Adillatuhâ wa Muhimmâtuhâ wa Tathbîquhâ, (Damaskus: Dâr al-Qalam, 1994), hlm. 158. Bandingkan dengan Zakariyâ al-Anshâri yang menyatakan :

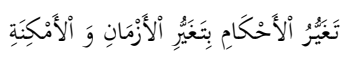

"Perubahan hukum lebih ditentukan oleh perubahan waktu dan tempat". Lihat, Zakariyâ al-Anshâri, Ghâyat al-Wushûl Sharh Lubb al-Ushûl, (Semarang: Maktabah Hidayah, tt), hlm. 67.

$$
360 \mid \text { JURNAL LISAN AL-HAL }
$$


Namun demikian, fiqh yang semestinya dinamis dan sangat dialektis pada kenyataannya harus terpetieskan oleh proses pensakralan, justru oleh para pendukungnya sendiri. Dalam konteks ini, fiqh menjadi tidak sekedar terbakukan, tetapi lebih dari itu, juga terbatukan dan terfosilkan ke dalam teks-teksnya. Pada tahap berikutnya menjadi rigid dan kaku. ${ }^{11}$

Kecurigaaan ini juga patut diajukan mengingat bahwa dinamika fiqh seolah terhenti, setelah pintu ijtihâd benar-benar telah tertutup, atau sengaja ditutup. Membongkar-bongkar kembali perihal teks ke-Islaman klasik yang acap kali diabaikan; 'urf atau 'âdah ${ }^{12}$ dalam tradisi Ushûl alFiqh. Tesa ini akan terus berkelindan dengan lokus 'urf, sebentuk adat lokal yang tersebar di berbagai daerah. Terlebih dengan asumsi bahwa Islam sebagai agama rahmatan lî al-'âlamîn idealnya harus meng-cover seluruh jenis keislaman yang mau tidak mau -dalam hal ini Fiqh dan Ushûl al-Fiqh - harus merespon praktek lokal, lebih-lebih juga sebagai pijakan sumber hukumnya.

Faktor 'keterdisinian' dan 'keterkinian' menjadi sebuah keniscayaan dalam memperlakukan hukum Islam (baca, fiqh) secara bijak dan adil. Karena sejatinya fiqh merupakan produk dialektika antara teks dan realitas. Maka menjadi sangat wajar -untuk tidak dikatakan seharusnya-jika kedatangan Islam ke muka bumi ini bukanlah suatu bentuk revolusi hukum yang secara langsung ditujukan untuk melawan

11 Pernyataan ini ditegaskan oleh Mohammed Arkoun, seorang pemikir Islam beraliran 'post-modernisme' asal Aljaza'ir ketika dia menjelaskan proses pembatuan seluruh teks-teks keislaman klasik yang menyebabkan taqdîs al-afkâr al-Islamî (sakralisasi pemikiran Islam). Perihal pemikiran yang sebenarnya masuk dalam lingkaran relatifisme, oleh ummat, bahkan malah dianggap sebagai buah absolusitas yang kedap kritik. Ironis memang. Tapi, itulah kenyataan yang sesungguhnya dibaca oleh Arkoun. Baca : Mohammed Arkoun, Berbagai Pembacaan al-Qurân, (Jakarta: INIS, 1995), hlm. 10.

12 Dalam konstelasi hukum Islam, 'urf dan 'âdah mempunyai sejarah semantik yang menarik. Secara literal, 'urf berarti sesuatu yang telah diketahui, sedangkan 'âdah bermakna pengulangan-pengulangan yang menjadi kebiasaan, adat. Dengan demikian, adat terbentuk akibat akumulasi dari pengulangan aktifitas yang berlangsung secara terus menerus. Ketika pengulangan ini membuatnya tertanam dalam jiwa setiap orang, maka dia telah memasuki ruang mu'taraf, yang diketahui. Meskipun kedua istilah ('urf dan 'âdah) ini nampak berbeda, namun dalam penggunaannya tidak mengandung perbedaan yang signifikan dengan konsekwensi hukum yang berbeda pula. Jadi meminjam istilah 'Abd al-Wahhâb Khallâf-hanya wal khulfu lafzhyyun, perbedaannya hanya pada tataran redaksi semata. Lebih jelasnya baca, 'Abd al-Wahhâb Khallâf, Op. Cit, hlm. 89, 'Abd al-Karîm Zaydân, al-Wajîz fî Ushûl al-Fiqh, (Beirut : Muassasah al-Risâlah, 2001), hlm. 252, dan Muhammad Shidqî bin Ahmad al-Burnû, al-Wajîz fî Îdhah al-Qawâ'id, (Beirut : Muassasah al-Risâlah, 1983), hlm. 155. 
adat-kebiasaan yang dipraktekkan bangsa Arab'13. Bahkan sahabat 'Umar ibn Khatthâb membuat statemen yang cukup revolusioner, bahwa Arab merupakan bahan baku (materi) Islam. Oleh karenanya, Arab -dengan segala adat-kebiasaannya - adalah mâdah yang menjadi asal mula, sumber dan pilarnya Islam ${ }^{14}$. Nabi Muhammad SAW -dalam kapasitasnya sebagai pembuat hukum-seringkali menciptakan aturan yang melegalkan kebiasaan masyarakat Arab. Konsep sunnah taqrîriyyah ${ }^{15}$ adalah sebagai bukti yang nyata bahwa Nabi memang membiarkan keberlakuan beberapa 'urf dan kebiasaan setempat yang bisa diterima.

Bisa dilihat, betapa Imâm Mâlik (93 - 179 H) -yang memiliki nama lengkap Mâlik ibn Ânas ibn Abî 'Amar al-Ashbahi-- dalam menetapkan hukum selalu berpegangan pada 'amal ahl al-Madînah (kebiasaan yang terjadi di masyarakat Medinah). Bahkan 'amal ahl al-Madînah bisa mengalahkan posisi hadits ahad sebagai sumber hukum ${ }^{16}$. Hal ini diamini oleh para pengikut setia madhhab Mâlikî. Misalnya, al-Qarâfî menegaskan bahwa seorang mujtahid dalam menetapkan suatu hukum terlebih dulu harus meneliti dan mengetahui adat kebiasaan yang berlaku dalam masyarakat setempat, sehingga hukum yang akan diputuskannya tidak bertentangan atau bahkan menghilangkan kemaslahatan masyarakat itu sendiri. ${ }^{17}$ Demikian juga, al-Shâthibî (w. 790 H) mendasarkan sumber hukumnya pada lokalitas tradisi yang beraneka ragam ${ }^{18}$.

13 Waliyullâh bin 'Abd al-Rahîm al-Dihlawî, Hujjat Allâh al-Bâlighah,Vol. I, (Kairo : Dâr al-Turâth, 1185 H), hlm. 124.

14 Khalîl Abd al-Karîm, al-Judhûr al-Târikhiyyah lî al-Sharî'ah al-Islamiyyah, terj. Kamran As'ad, (Yogyakarta : LkiS, 2003), hlm. 1.

15 Sunnah Taqrîriyyah adalah salah satu bentuk hadîth Nabi -selain sunnah qawliyyah dan sunnah fi'liyyah-yang merujuk pada suatu perbuatan atau kebiasaan masyarakat Arab pada masa Nabi dan beliau mebiarkannya, tidak mencegahnya.

16 Bahkan Imam Mâlik memandang 'amal ahl Madînah sebagai sumber hukum otoritatif. Oleh sebab tradisi Madinah merupakan praktik kolektif penduduk Madinah yang telah berlangsung secara umum, turun-temurun dan sudah mapan. Hal ini dipadankan dengan hadîth mutawâtir, sehingga ketika berhadapan dengan khabar ahad maka posisi khabar ahad itu menjadi lemah. Lihat, Yasin Dutton, Asal Mula Hukum Islam; Al-Qurân, Muwaththa' dan Praktik Madinah, (Jogyakarta: Penerbit Islamika, 2003), hlm. 75-106. Bandingkan Muhammad Hâshim Kamâlî, Sharî'ah as Understood by the Classical Jurist, (Law Journal, 1\&2, 1998), hlm. 75-76.

17 Abdul Wahhâb Khallâf, Mashâdir al-Tashrî̀ al-Islamî fî mâ Lâ Nash Fîhi, (Beirut: Dâr al-Qalam, 1978), hlm.149.

18 Dia menyediakan bab tersendiri yang membahas seputar adat kaitannya dengan perkembangan hukum Islam. Lihat, Abû Ishâq Ibrâhîm ibn Mûsâ al-Lakhmî al-Shâthibî, Op. Cit., hlm. 194-209.

$362 \mid$ JURNAL LISAN AL-HAL 
Adanya dinamika masyarakat dan pergeseran zaman menuntut adanya perubahan hukum. Faktor-faktor ini harus dijadikan pertimbangan agar hukum yang ingin diterapkan dalam tataran masyarakat lebih membawa kamaslahatan dan punya kepastian hukum. Al-Shâthibi menegaskan bahwa perubahan hukum secara dinamis lebih banyak dipengaruhi oleh perubahan adanya dinamika kebiasaan masyarakat, walau secara pasti perubahan tersebut tidak sampai merubah substansi khitâb (titah Shâri'). Keberadaan adat kebiasaan ${ }^{19}$ itu hanya akan digunakan shara' sebagai parameter untuk memahami hukum yang responsif dan adaptif. 20

Al-Shât\}ibi menerima dan menjadikan adat kebiasaan sebagai dalil shar'î dalam menetapkan hukum. Kebiasaan universal yang secara tegas diakui oleh nas\}s\} berfungsi sebagai media untuk memahami dan menerjemahkan hukum Islam dalam menjelaskan hukum suatu problem sosial yang dihadapi masyarakat. ${ }^{21}$ Upaya terbaik adalah menjaga keberlakuan kebiasaan yang beragam tersebut sebagai pertimbangan hukum dan pijakan dalam memberlakukan hukum Islam atas prinsipprinsip tata aturan yang dilandaskan pada semangat Al-Qurân dan H\}adîth Nabi. ${ }^{22}$

Dia membedakan kebiasaan yang terjadi di masyarakat pada dua macam. Pertama, al-áwâid al-shar'iyyah, yaitu tradisi atau kebiasaan yang diamini oleh nash atau dalil shar'î. Kedua, al-'awâid al-jâriyyah, yakni sebentuk kebiasaan yang telah berlangsung lumrah di masyarakat, sementara shara' tidak memberikan tanggapan, tidak menolak ataupun menerima. Kebiasaan jenis pertama diterima oleh shara' karena dia bersesuaian dengan idealisme shara' itu sendiri. Sementara untuk kebiasaan jenis kedua bersifat tidak mengikat dan karenanya dipersilahkan untuk diberlangsungkan. ${ }^{23}$ Dalam karya monumentalnya,

19 Dalam menyebutkan kebiasaan yang berlaku di masyarakat, Al-Shâthibî menggunakan istilah áwâid atau 'âdât sebagai kata plural dari 'âdat-meskipun tidak secara konsisten--, bukan 'urf. Lihat, Abû Ishâq Ibrâhîm ibn Mûsâ al-Lakhmî al-Shâthibî, Op. Cit., hlm. 183-215 Akan tetapi, penulis lebih melihat bahwa hal itu hanya al-khulf lafdhiyyun, perbedaan istilah yang maknanya bermuara pada segala bentuk praktek -baik dalam perkataan maupun perbuatan-yang sudah lumrah terjadi dalam suatu komunitas tertentu.

20 Abû Ishâq Ibrâhîm ibn Mûsâ al-Lakhmî al-Shâthibî, al-I'tishâm,Vol. II, (Beirut: Dar al-Fikr, tt), hlm. 199.

21 Ibid, hlm. 200.

${ }^{22}$ Abû Ishâq Ibrâhîm ibn Mûsâ al-Lakhmî al-Shâthibî, al-I'tishâm,Vol. II, (Beirut: Dar al-Fikr, tt), hlm. 78.

${ }^{23}$ Abû Ishâq Ibrâhîm ibn Mûsâ al-Lakhmî al-Shâthibi >, al-Muwâfaqât...,hlm. 209- 
kitab al-Muwâfaqât fî Ushul al-Ahkâm, al-Shâthibî menyediakan bab khusus yang membicarakan secara khusus tentang kebiasaan ('âdah). Kebiasaan yang lumrah terjadi dalam satu komunitas tertentu mendapatkan legitimasi dari shara' selama tidak berhadapan secara diametral dengan nash-nash Shar'î.

Hal ini menarik untuk dikaji, oleh sebab persoalan-persoalan yang muncul di tengah-tengah masyarakat terus melaju dan meminta jawaban konkrit dari hukum Islam. Sementara, nash sebagai dalil shara' secara tekstual sudah selesai pasca wafatnya Nabi saw. Oleh sebab itu, perlu mencari jalan alternatif guna menemukan landasan hukum yang diamini oleh Shâri'. Salah satu yang dijadikan landas-tumpu dalam penetapan hukum Islam adalah 'urf atau 'âdah, satu bentuk kebiasaan lokal masyarakat tertentu. Dan ide penetapan dan pemberlakuan hukum Islam -lebih-lebih dalam konsep nation state (negara-bangsa)-- senantiasa menemukan jalan buntu diantara penantian panjang umat Islam untuk menjadikan hukum Islam sebagai payung hidupnya. Selama ini ditengarai, para pembuat hukum tidak selalu memperhatikan kebiasaan, kondisi, dan sosio-kultural masyarakat di mana hukum akan ditetapkan. Maka, urgensitas 'urf dalam rancang bangun hukum Islam beserta dinamikanya menjadi sesuatu yang niscaya untuk dibahas. Hal ini dilakukan dalam rangka membumikan hukum Islam pada dataran realitas. Sehingga hukum tidak hanya menjadi 'menara gading' yang tidak pernah menyapa manusia yang senantiasa mendamba keadilannya.

\section{B. 'Urf dalam Pembentukan Hukum Islam}

Ajaran Islam tidak datang ke dunia ini secara instan, menyapa realitas dalam ruang hampa dan lembaran kosong. Islam hadir dari hasil perjumpaan dan persinggungan dengan realitas sosial yang mengitarinya. Kenyataannya, Al-Qurân diturunkan dalam bahasa Arab $^{24}$ yang notabene adalah bahasa manusia, serta melalui perantara Nabi Muhammad SAW. yang juga seorang manusia25. Dan banyak diantara ayat-ayat Al-Qurân maupun H\}adîth Nabi SAW. yang merupakan jawaban atas pertanyaan para sahâbat kala itu. Dengan kata lain, jarang sekali nash-nash shar'î itu diturunkan atau disabdakan tanpa ada sebab-sebab yang melatarinya. Maka pergumulan antara sharî‘ah Islam dengan kultur masyarakat

210.

${ }^{24}$ QS. Yûsuf [12], 2

${ }^{25}$ QS. Ibrâhîm [14], 10-11 dan QS. Yâsîn, [36], 15

$364 \mid$ JURNAL LISAN AL-HAL 
bukanlah sesuatu yang baru. Sejak Islam pertama kali datang, ia telah berbaur dengan kultur dan budaya masyarakat Arab dengan segala variannya.

Istilah asbâb al-nuzûl dalam kajian 'Ulûm Al-Qurân, dan asbâb alwurûd dalam disiplin 'Ulûm al-Hadîth maupun Ushûl al-Fiqh, bukan sekedar istilah kosong yang hambar makna. Istilah tersebut mengindikasikan pentingnya pengetahuan tentang setting pewahyuan yang selalu terkait dengan situasi, kondisi, atau lanskap tertentu bagi seorang mufassir atau mujtahid. Demikian pula, term ayat-ayat Makkiyyah dan Madaniyyah dalam 'Ulûm Al-Qurân menunjukkan bahwa ayat-ayat yang diturunkan di Mekkah dan Medinah memiliki karakteristik masingmasing sesuai dengan realitas sosial yang dihadapi kaum Muslimin saat itu. ${ }^{26}$ Ini semua merupakan bukti otentik bahwa ada hubungan dialektis antara nash sharî'ah (baca, Al-Qurân dan al-Hadîth) dengan realitas sosiokultural. Dalam konstruksi fiqh -yang terdaftar dalam lembaran-lembaran kitab kuning--, banyak kita temukan praktek-praktek keagamaan, baik 'ubûdiyah (hubungan vertikal) maupun mu'âmalah (hubungan horizontal), yang merupakan hasil adopsi tradisi Arab pra-Islam. Ibadah haji, umroh, hadd al-zinâ dan mencuri, minum khamr, qishâsh, diyat, qasâmah dan 'âqilah, sampai perbudakan dan poligami ${ }^{27}$ adalah beberapa sampel tradisi Arab yang dibangun dan dirumus ulang dalam konstruksi hukum-hukum Islam.

Rekrutmen adat-istiadat atau tradisi masyarakat Arab ke dalam hukum Islam, ${ }^{28}$ mengambil tiga pola. Pertama, sharî'ah mengambil sebagian tradisi itu dan membuang sebagian lainnya. Kedua, Islam mengambil sebagian dan membuang sebagian yang lain, dengan melakukan penambahan dan pengurangan di sana-sini. Dan ketiga, Islam mengadopsinya secara utuh tanpa adanya perubahan bentuk dan identitasnya. Tapi dari ketiga pola adopsi ini, Islam sendiri sama sekali

26 Adalah Mahmoud Mohammed T\}âhâ (w. 1985), seorang pemikir dan pendiri Persaudaraan Republik di Sudan, menegaskan bahwa ayat-ayat Makkiyyah adalah pesan yang abadi dan fundamental yang inhern pada seluruh umat manusia, tanpa melihat perbedaan gender, keyakinan, ras dan semacamnya yang kemudian dikenal dengan ayat universal-egalitarian-demokratik. Sedangkan ayat-ayat Madaniyyah disebut dengan ayatayat sektarian-diskriminatif karena hanya merupakan bentuk implementasi dakwah untuk diterapkan pada lapangan praktis. Lebih jelasnya, lihat Abdullâh Ah\}med An-Na'îm, Dekonstruksi Syari'ah,Wacana Kebebasan Sipil, Hak Asasi Manusia dan Hubungan Internasional dalam Islam, (Jogyakarta : LKiS, 1994), hlm. 102-111.

27 Khalîl 'Abd al-Karîm, al-Judhûr al-Târîkhiyyah lî al-Sharî‘ah al-Islâmiyyah, terj. Kamran Asád, (Yogyakarta: LKiS, 2003), hlm. 21-22.

${ }^{28}$ Ibid. 
tidak mengubah hukum-hukum inti, konsep-konsep dasar, apalagi nashnash qath'î-nya.

Dari sudut pandang yang berbeda, 'Abd al-Karîm Zaydân juga menganalisa tiga pola penyerapan sharî‘ah terhadap budaya mayarakat Arab. ${ }^{29}$ Pola pertama, Nabi saw. banyak mengadopsi budaya-budaya Arab yang bernilai positif sementara kebiasaan-kebiasaan negatif ditinggalkan. Kedua, hakikat penerapan adat sebenarnya merupakan pemberlakuan dalil-dalil shar'î itu sendiri. Artinya, bila adat itu dijadikan acuan maka sejatinya hukum yang diancang adalah hukum yang didasarkan pada dalil nash (selain al-Quran-Hadîth, seperti ijma', istihsân, mashlahah mursalah, maupun sadd al-dharî'ah ${ }^{30}$. Contoh tradisi yang berdasarkan ijma' dapat kita lihat pada pemberlakuan akad istis\}nâ' yakni transaksi pembelian barang yang hendak dibuat. ${ }^{31} \mathrm{Hal}$ ini diamini, karena akad tersebut telah menjadi satu kebutuhan masyarakat yang cukup mendesak. Jika tradisi yang menjadi kebutuhan dasar ini dihapus, maka masyarakat akan menghadapi banyak kesulitan. Selama tradisi itu baik (shahîh) dan menolak mafsadah, maka selama itu pula pemeliharaan atas tradisi merupakan bagian dari mashlahah mursalah. ${ }^{32}$ Yang ketiga, bahwa para fuqaha pada perkembangan berikutnya lebih bersikap kooperatif dan

29 'Abd. Al-Karîm Zaydân, al-Wajîz fî Ushûl al-Fiqh, (Amman: Maktabah al-Bathâir, 1994), hlm. 254-255.

30 Secara sederhana Sadd al-dharî'ah adalah upaya untuk menghalangi dan memblokade semua akses dan kemungkinan yang dapat mengantarkan pada segala jenis kerusakan dan kemadlaratan dalam segala jenis dan motifnya. Lihat, 'Abd al-Karîm Zaydân, Op.cit., 245. Sebetulnya, ada istilah fath\} al-dharîáh -yang seringkali dilupakan banyak orang-yaitu hal-hal yang bisa mengantarkan seseorang kepada kedekatan (taqarrub) kepada Allah dan kemaslahatan umat. Oleh sebab itu, jika ada sesuatu yang bisa mengantarkan pada kerusakan, maka harus diantisipasi yang disebut dengan sadd al-dharîáh. Tetapi kalau membawa kemaslahatan, maka hal itu harus dibuka lebar-lebar. Inilah fath al-dharîáh. Karena status sarana hukumnya sama dengan tujuannya (lî alwasâil hukm al-maqâshid). Lebih jelasnya, baca Wahbah al-Zuhailî, Ushûl al-Fiqh al-Islâmî, Vol. II, (Beirut: Dâr al-Fikr al-Muáshir, 1989), hlm. 873-874 dan Állâl al-Fâsî, Maqâshid alSharîah al-Islâmiyyah wa Makârimuhâ, (Beirut: Dâr al-Gharbî al-Islâmî, 1991), hlm. 158162.

31 ' Abd. Al-Karîm Zaydân, al-Wajîz fî Ushûl al-Fiqh, (Amman: Maktabah al-Bathâir, 1994), hlm. 255 dan Wahbah al-Zuhailî, Ushûl al-Fiqh al-Islâmî, Vol. II, (Beirut: Dâr al-Fikr al-Muáshir, 1989), hlm. 35.

${ }^{32}$ Hal ini sebenarnya sudah pernah ditengarai oleh al-Sharkhâs\}î. Walaupun tidak secara eksplisit beliau mengklaim bahwa pemeliharaan atas adat adalah bagian dari konsep maslahah mursalah. Untuk lebih jelasnya, Muhammad bin Ah\}mad Abû Sahl AlSarkhâshî, Al-Mabsûth, Vol. XIV, (Beirut: Dâr al-Fikr, tt), hlm. 14

$366 \mid$ JURNAL LISAN AL-HAL 
apresiatif terhadap 'urf yang berkembang di masyarakat. Hal ini menjadi bukti bahwa pemeliharaan atas tradisi merupakan sesuatu yang tidak bertentangan dengan ajaran Islam. ${ }^{33}$

Sebetulnya kata 'urf, merupakan derivasi dari kata 'arafa - ya'rifu 'urfan, yang berarti mengetahui ${ }^{34}$. Kemudian secara sederhana 'urf didefinisikan sebagai :

$$
\text { العرف هو ما استقر في النفوس و تلقته الطباع السليمة بالقبول }
$$

"Sesuatu yang menetap dalam jiwa secara rasional dan diterima oleh watak yang sehat"35.

Sementara 'Abd al-Wahhâb Khallâf mendefinisikan 'urf sebagai berikut :

$$
\text { العرف هو ما يتعارفه الناس و يسيرون عليه غالبا من قول أو فعل }
$$

"Sesuatu yang dikenal manusia dan dijalankan secara biasa, baik berupa perkataan atau perbuatan". ${ }^{36}$

Sementara, makna yang sepadan dengan 'urf, adalah 'âdat ${ }^{37}$ yang berasal dari akar kata 'âda - ya'ûdu - 'âdatan, yang memiliki arti pengulangan. ${ }^{38}$ Secara literal, 'urf dimaknai dengan apa yang telah dikenal. Dan adat memiliki arti pengulangan perbuatan atau praktek yang dilakukan secara berulang-ulang. ${ }^{39}$ Atau aturan (perbuatan dan semacamnya) yang lazim dituruti atau dilakukan semenjak dahulu sehingga sudah menjadi satu kebiasaan ${ }^{40}$. Adat secara terminologis

33 "Abd. Al-Karîm Zaydân, al-Wajîz fî Ushûl al-Fiqh, (Amman: Maktabah al-Bathâir, 1994), hlm. 255.

${ }^{34}$ Abû al-Fadhl Jamâluddîn Muhammad bin Mukarram ibn Manzûr, Op. Cit, Vol. IV, hlm. 311.

35 Mûsâ Ibrâhîm al-Ibrâhîm, al-Madkhal Ilâ Us\}ûl al-Fiqh wa Târîkh al-Tashrî’ alIslâmî, (Amman Yordania: Dâr 'âmmâr, 1989), hlm. 75.

${ }^{36}$ Abdul Wahhâb Khallâf, Mashâdir al-Tashrî’ al-Islamî fî mâ Lâ Nash Fîhi, (Beirut: Dâr al-Qalam, 1978), hlm. 145.

37 Beberapa kalangan terpolar pada dua mainstream pemikiran yang berbeda; pertama, mereka yang membedakan secara mencolok antara 'urf dengan adat. Dan kedua, mereka yang menyepadankan 'urf dengan adat. Alur yang pertama, menandaskan betapa 'urf dan adat adalah bukan sinonim. Dalam konteks ini, 'urf hanya sekedar adat kebiasaan yang sering dilakukan oleh orang. Sementara, adat lebih luas cakupannya; tidak hanya individu saja, melainkan sudah menjadi kebiasaan kolektif dalam sebuah masyarakat. Dengan demikian, adat lebih umum dari pada 'urf. Baca, Musthafâ Ahmad al-Zarqâ', alMadkhal al-Fiqhiyy al-'Âm, Vol. II, (Damaskus: Matba'ah Tharayain, 1968), hlm. 841.

38 Abû Fadhl Jamâluddîn Muhammad bin Mukarram ibn Manzhur, Lisân al-'Arab, Vol. XIII, (Beirut : Dâr al-Fikr, tt), hlm. 123.

39 Muhammad Hâshim Kamâlî, Principles of Islamic Jurisprudence, (Cambridge: Islamic Texts Society, 1991), hlm. 283.

40 Departemen Pendidikan dan Kebudayaan RI, Kamus Besar Bahasa Indonesia, \begin{tabular}{l|l} 
JURNAL LISAN AL-HAL & 367
\end{tabular} 
diartikan sebagai :

$$
\text { العادة عبارة عما يستقر في النفوس من الأمور المتكررة المقبولة عند الطباع السليمة }
$$

"Norma yang sudah melekat dalam hati akibat pengulang-ulangan, sehingga diterima sebagai sebuah realitas yang rasional dan layak menurut penilaian akal sehat" ${ }^{41}$

Norma tersebut bisa dilakukan oleh individu atau kelompok masyarakat. Secara dasariyah, kedua istilah ini bertemu pada satu titik pengertian, yaitu sesuatu yang diterima akal sehat, tertanam dalam hati dan dilakukan berulang-ulang. Karena pada tataran praktisnya, para fuqahâ' tidak membedakan kedua istilah tersebut. Keberbedaan antara 'urf dengan adat yang seringkali dipersoalkan oleh sebagian ulama tersimpul pada dua hal pokok; intensitas keberlakuannya dan kuantitas pelakunya. Jelas, bahwa adat lebih unggul dari pada 'urf pada dua bidang yang dimaksud tersebut. ${ }^{42}$

Jika mengamati definisi 'urf, tampak bahwa ia hampir serupa dengan ijmâ' yang juga (sama-sama) menjadi sumber hukum Islam. ${ }^{43}$ Namun demikian, sesungguhnya terdapat beberapa perbedaan mencolok antara 'urf dan ijmâ'. Bahwa ijmâ' dibangun atas kesepakatan para mujtahid (pakar dalam istinbâth al-Ahkkâm). Sementara 'urf, tidak dibangun atas kesepakatan tersebut, karena lebih mencukupkan dengan ketetapan orang banyak, baik kalangan khâsh ataupun 'awamnya. ${ }^{44}$ Lebih dari itu, dalam ijmâ' meniscayakan kesepakatan seluruh peserta ijmâ' tanpa kecuali, sedang dalam 'urf, ketidakbersediaan sebagian kalangan

(Jakarta: Balai Pustaka, 1989), hlm 6.

41 Zain al-'Âbidîn bin Ibrâhîm bin Nujaim, al-Ashbâh wa al-Nazhâir 'alâ Madhhab Abî Hanîfah al-Nu'mân, (Beirut: Dâr al-Kutub al-'Ilmiyyah, 1993), hlm. 93.

42 Adat adalah sebuah kecenderungan (berupa ungkapan atau pekerjaan) pada satu obyek tertentu, sekaligus pengulangan akumulatif pada obyek pekerjaan dimaksud, baik dilakukan oleh pribadi atau kelompok. Akibat akumulasi pengulangan itu, ia kemudian dinilai sebagai hal yang lumrah dan mudah dikerjakan. Aktivitas itu telah mendarah-daging dan hampir menjadi watak pelakunya. Tak heran jika di dalam idiom Arab, adat dianggap sebagai tabiat kedua manusia. Lihat, 'Abd. Al-Karîm Zaydân, Op. Cit., hlm. 252.

43 Sebagaimana diketahui, sumber-sumber hukum Islam ada dua bentuk; Pertama, sumber yang muttafaq 'alaih (yang disepakati) yaitu ada empat; al-Qur'ân, al-Sunnah, Qiyâs dan Ijmâ'. Kedua, sumber hukum yang masih diperselisihkan keberlakuannya (mukhtalaf fîh) antara lain; Istihsân, Istishâb, Sadd al-Zharî'ah, Shar'u man Qablanâ, 'Urf, Qaul al-Shahâbî, 'âmal Ahl Madînah dan lain sebagainya.

${ }^{44}$ Wahbah al-Zuhailî, Ushûl al-Fiqh al-Islâmî, Vol. II, (Beirut: Dâr al-Fikr al-Muáshir, 1989), hlm. 829.

$368 \mid$ JURNAL LISAN AL-HAL 
atasnya, tidaklah menggagalkan keberadaan 'urf tersebut. ${ }^{45}$

Secara umum, terdapat empat sharat bagi sebuah tradisi untuk bisa dijadikan sebagai pijakan hukum ${ }^{46}$ yaitu :

Pertama, Kebiasaan tersebut berlaku konstan (iththirâd) dan menyeluruh, atau minimal dilakukan kalangan mayoritas (ghâlib). Bilapun ada yang tidak mengerjakan, maka itu hanya sebagian kecil saja dan tidak dalam bentuk yang dominan. Yang dimaksud konstan disini adalah bersifat umum dan sulit sekali untuk berubah-ubah dari waktu ke waktu.

Kedua, 'urf sudah terbentuk sebelum atau bersamaan dengan masa penggunaannya. Oleh sebab itu, muncullah sebuah kaidah, Lâ 'ibrata bi al'Urf al-Thâri', kebiasaan yang baru muncul itu tidak diperhitungkan. ${ }^{47}$

Ketiga, Tidak terdapat ucapan atau pekerjaan yang nyata-nyata bertentangan dengan nilai-nilai substansial 'urf. Hukum ini sesuai dengan kaidah; mâ yathbutu bi al-'urf bidûni dhikr, la yathbutu idhâ nush 'alâ khilâfih (segala hal yang ditetapkan oleh adat tanpa disebutkan, tidak bisa dilegalisasi bila dilakukan kebalikannya) ${ }^{48}$.

Keempat, 'Urf tidak bertentangan dengan teks sharî'at. Artinya 'urf tersebut berupa 'urf shahîh, yaitu bahwa 'urf tersebut tidak sampai menganulir seluruh aspek substansial nash. Sebab bila isi substantif nash tidak teranulir, maka tidak dinamakan bertentangan dengan nash, karena masih terdapat beberapa unsur nash yang tak tereliminasi. Dengan demikian, unsur-unsur positif 'urf yang berseberangan dengan nash bisa dipelihara dan dijadikan pondasi hukum, sementara bagian-bagian nash yang tidak terhapus oleh 'urf juga bisa dijadikan acuan hukum. Kedua unsur ini bisa diambil sebagai pondasi hukum ditinjau dari aspek positifnya masing-masing. ${ }^{49}$

Tepat dititik inilah kita menemukan urgensi terdalam dari sharat yang diajukan ulama, bahwa adat-istiadat yang dapat diadopsi hanyalah adat yang tidak bertentangan dengan dalil nash. Penting diingat, bahwa

45 'Abd. Al-Wahhâb Khallâf, Mas\}âdir at-Tashri' fî mâ lâ nash fîhi, hlm. 146-147.

46 Muhammad al-Rûkî, Qawâ'id al-Fiqh al-Islâmî min Khilâl Kitâb al-Ishrâf 'alâ Masâil al-Khilâf, (Damaskus: Dâr al-Qalam, 1998), hlm. 218-220. Bandingkan dengan Mushthafâ Ahmad al-Zarqâ', Op. Cit, hlm. 873-881, Abd. Al-Karîm Zaydân, al-Wajîz fî Ushûl al-Fiqh, (Amman: Maktabah al-Bathâir, 1994), hlm 256-257, 'Abdullâh 'Abd al-Muh\}sin al-Turkî, Op cit, hlm. 528-530. dan Shauqî Ábduh al-Sâhî, Al-Madkhal li Dirâsah al-Fiqh alIslâmî, (Kairo: al-Maktabah al-Nahdhiyyah al-Mishriyyah, 1989), hlm. 292-293.

47 Zain al-'Abidîn bin Ibrâhîm bin Nujaim, Op. Cit, hlm. 101.

48 Abû Muhammad 'Izz al-Dîn ibn 'Abd. Al-Salâm al-Sulamî, Qawâ'id al-Ahkâm fî Mashâlih al-Anâm, Beirut: Dâr al-Kutub al-Ílmiyyah, tt, hlm.178.

${ }^{49}$ Abd. Al-Karîm Zaydân, al-Wajîz fî̀ Ushûl al-Fiqh, (Amman: Maktabah al-Bathâir, 1994), hlm. 256. 
yang demikian merupakan prasharat keberlakuan 'urf secara sempurna dan utuh. Padahal sesungguhnya, prasharat minimal keberlakuan 'urf hanyalah dua; ketetapan (al-istiqrâr) dan kontinuitas (al-istimrâr) ${ }^{50}$.

Tanpa prasharat ini, keberlakuan 'urf memang patut digugat mengingat bahwa inilah sesungguhnya yang menjadi pondasi awal 'urf. Bagaimana mungkin, ia diabsahkan sebagai 'urf yang alih-alih dijadikan sumber primer dalam istinbâth al-ahkâm (penggalian dan penmunculan sebuah hukum) sementara ia sendiri bukan merupakan kebiasaan yang diakui keberadaannya oleh individu-individu yang terlibat dalam proses pembentukan 'urf. Bagaimana pula, ia dapat diangkat sebagai 'urf yang diamini adanya, padahal ia tidak mempersharatkan 'kontinuitas', yang merupakan komuditas berharga dalam diskursus mengenai Fiqh-Ushul alFiqh. Oleh sebab itulah, adalah faktor alami, proses terbentuknya 'urf sehingga benar-benar menjadi sumber ketetapan hukum dalam Islam.

\section{Pemikiran Al-Shâthibî tentang 'Urf}

Masa muda Al-Shâthibi ${ }^{51}$ berada pada zaman keemasan Islam di Granada, di bawah pemerintahan Sultan Muhammad V al-Ghanî Billâh. Granada merupakan pusat studi yang menjadi sentra perhatian para pelajar dan ulama dari seluruh pelosok Afrika Utara. ${ }^{52}$ Diantara tokoh hlm. 193.

${ }^{50}$ Abû al-Ishâq Ibrâhîm bin Mûsâ bin Muhammad al-Lakhmî al-Shâthibî, Op. Cit.,

${ }^{51}$ Nama lengkapnya adalah Abû Ishâq Ibrâhîm bin Mûsâ bin Muhammad al-Lakhmî al-Gharnathî, yang kemudian dikenal dengan nama al-Shât\}ibî. Tidak ditemukan data yang akurat tentang tanggal, tahun dan tempat dia dilahirkan. Yang bisa dipastikan adalah bahwa dia berasal dari keluarga yang bersahaja keturunan suku Arab Lakhmî, sehingga di ujung namanya terdapat kata al-Lakhmî. al-Shâtibi tumbuh hingga dewasa dan menjalani seluruh etape pendidikannya di Granada. Ada dugaan, bahwa keluarga AlShâthibî berada di Granada sampai akhir hayat mereka. Dan Al-Shâtibi menghadap Sang Pencipta pada tanggal 8 Sha'bân tahun 790 H atau 1388 M.

Penisbatan Shâthibi ini dialamatkan pada latar belakang keluarganya yang berasal dari Shathibâ (Xativa atau Jativa di Spanyol bagian timur). Hal ini yang membuat I. Golziher dan Brockelmann -ketika mengkaji al-Shâthibî—mengatakan bahwa al-Shâthibi lahir dan hidup di Shâthiba sebelum hijrah ke Granada. Akan tetapi, tesis itu diyakini oleh M. Khalid Mas'ud sebagai sebuah kekeliruan yang sangat fatal. Karena menurut catatan sejarah, kota Shâthibâ ketika itu telah diambil alih oleh kaum salib dan segenap kaum muslim telah dideportasi dari Shâthiba pada tahun 645 H/ 1247 M. Lebih satu abad sebelum kelahiran Shâthibi. Dan mayoritas dari mereka melarikan diri ke Granada. Lebih jelasnya, baca M. Khalid Mas'ud, Islamic Legal Philosofy; A Study of Abu Ishaq al-Shatibi's, Life and Thought, terj. Yudian W. Asmin, (Surabaya : al-Ikhlas, 1995), hlm. 109.

52 Abû al-Ajfân menyatakan bahwa al-Shâthibî berdomisili di Granada dan ia besar

$370 \mid$ JURNAL LISAN AL-HAL 
yang sering mengunjungi ibukota Kerajaan Banû Nashr itu adalah Lisân alDîn Ibn Khathîb (w. 776 H/ 1374 M), Ibnu Khaldûn (w. 784 H/ 1382 M) dan Abû Abdillâh al-Maqarrî (w. 758 H) ${ }^{53}$.

Meskipun tahap pengembaraan intelektual yang ditempuhnya hanya berkisar di kota Granada, namun pemikiran-pemikiran al-Shâthibî selalu menjadi rujukan utama diskursus pembaharuan hukum Islam ${ }^{54}$. Hal ini tidak lepas dari kerakusannya dalam menuntut ilmu. Perjalanan pendidikannya diawali dengan mempelajari bahasa Arab yang ditimba dari Abû 'Abdillâh Muhammad bin 'Alî al-Fakhkhâr al-Ilbîrî (w.754 H/ 1353 M) ${ }^{55}$, Abû Abdillâh al-Bâlinsi, Abû al-Qâsim Muhammad bin Ah\}mad al-Sharîf al-Sabthi $\left(760\right.$ H/ 1358 M) dan Abû Ahmad Ja'far al-Shaqwarî. ${ }^{56}$ Sedangkan dalam bidang ilmu hadîth, Shât\}ibi banyak belajar pada Abû alQâsim dan Shamsuddîn al-Tilimsânî (w. 781 H). Setelah itu, Shât\}ibi muda menggali ilmu fiqh dari Abû Sa'îd al-Lubb, seorang faqîh Andalusia yang terkenal. Dari beliaulah, Shâthibi mendapatkan hampir seluruh pengetahuannya dalam disiplin ilmu fiqh.

Bagaikan orang dahaga yang minum air laut tidak pernah merasa puas, Shât\}ibi muda tidak pernah mengenal kata henti dalam menimba ilmu. Dia juga belajar banyak dari ulama pendatang, salah satunya adalah Abû 'Abdillâh al-Maqarri --salah seorang ulama muhaqqiq fiqh dalam madhhab Mâlikî-yang memperkenalkan al-Shât\}ibi pada seluk beluk

serta tumbuh dewasa di kota Shathiba. Ada yang memperkirakan bahwa Shâthibi lahir di Granada ketika Yûsuf Abû al-Hajjâj memerintah Granada tahun 1333-1354 M. Baca, Ahmad al-Raisûnî, Nazhariyat al-Maqâshid 'Inda al-Imâm al-Shâthibî, (Herndon, Virginia : al-Ma'had al-'Âlamî li al-Fikr al-Islâmî, 1995), hlm. 90-108.

53 Al-Maqarrî adalah seorang tokoh yang datang ke Granada pada tahun $757 \mathrm{H} /$ 1356 dalam misi diplomatik yang dikirim oleh Marini Sultan Abû Inân. Dia adalah penulis kitab-kitab al-Qawấd al-Fiqhiyyah dan al-Haqâiq wa al-Raqâiq fî al-Tasawwuf (kitabkitab yang mengulas tentang tasawwuf dan para sufi, terutama silsilah para guru tasawwuf). Lihat, Ahmad al-Raisûnî, Op. cit, 91 dan Harif Susmana, Shâthibî, Tokoh Pembaharu yang Terlupakan, (dalam majalah Islamana, Jakarta, Thn I, No 1, Muharram 1425/Maret 2004), hlm. 108.

54 Kalangan pemikir Islam avan-gardis yang seringkali mereferensi pemikiran alShâthibi adalah Muhammad 'Abduh, Muhammad Iqbal, Fazlurrahman, 'Allâl al-Fâsî dalam karyanya Maqâshid al-Sharî'ah wa Makârimuha, dan Muhammad al-Thâhir ibn 'Ashûr dengan kitabnya Maqâshid al-Sharî́ah al-Islâmiyyah.

55 Al-Ilbiri terkenal sebagai guru gramatika bahasa Arab (shaikh al-nuhât) di Andalusia. Dan al-Shâthibi tinggal bersama gurunya ini sampai beliau meninggal dunia pada tahun 754 H/ 1353 M. Lihat, Ahmad 'Abd al-Shâfî, dalam pengantar Abû al-Ishâq Ibrâhîm bin Mûsâ bin Muhammad al-Lakhmî al-Shâthibî, al-I'tishâm, Vol. I, (Beirut : Dâr al-Kutub al-'Ilmiyyah, 1995), 8. Bandingkan dengan M. Khalid Mas'ud, Op. cit, hlm. 110.

${ }^{56}$ Ahmad al-Raisûnî, Op. cit,hlm. 109. 
Ushûl al-Fiqh dan tarekat Shâdhiliyyah ${ }^{57}$. Metodologi istinbâth hukum, juga didapat dari Abû Abdillâh Muhammad bin Ahmad al-Mâlikî alTilimsânî (w. 771 H/ 1369 M), imam ternama madhhab Mâlikî di Spanyol ${ }^{58}$. Tidak hanya dalam bidang bahasa, Fiqh dan Ushul al-Fiqh yang digeluti oleh al-Shâthibi. Akan tetapi, al-Shâthibi juga mendalami ilmu logika -filsafat, teologi, kalam dan ilmu-ilmu logika lainnya-dari beberapa ulama pada zamannya. Antara lain al-Shâthibi mendapat bimbingan khusus dari Abû 'Ali al-Manshûr al-Zawawî (w. 770 H/ 1369 M) yang datang ke Granada ${ }^{59}$ pada tahun $753 \mathrm{H} / 1352 \mathrm{M}^{60}$ dan juga menimba ilmu dari Abû al-Abbâs al-Qabâb dan Abû Abdillâh al-Hifâr.61

Ia adalah Ushûlî (ahli dalam us\}ûl al-fiqh), Mufassir (ahli tafsir), Faqîh (ahli dalam fiqh), Muhaddith (ahli hadith), Lughawî (ahli bahasa), Bayânî, Nazhâr (pemikir), Thâbit (teguh pendiriannya), Wâri' (orang yang wara'), Shâlih, Zâhid, Sunnî, Imam Mutlaq, Bahhath (peneliti), Jadalî (ahli debat), Bâri' fi al-'Ulûm (keilmuannya mendalam), dan lain-lain. ${ }^{62}$ Ketokohan Shâthibî sebagai ilmuwan dibuktikan juga dengan deretan muridnya yang menjadi pemikir garis depan, yaitu Abû Yahyâ bin 'Âshim, Abû Bakr bin 'Âshim (pengarang kitab Tuhfat al-Hukkâm), Abû 'Abdillâh al-Bayânî, Abû Ja'far al-Qashâr, dan Abû 'Abdillâh al-Majârî.63

Karya-karya yang belum diterbitkan, antara lain Kitâb al-Majâlis, sebuah kitab yang mengomentari tentang jual beli dalam Shahîh alBukhârî, Sharh al-Alfiyah, kitab nahwu sebagai komentar dari kitab Alfiyah Ibnu Mâlik, 'Unwân al-Ittifâq fî 'Ilm al-Ishtiqaq, dan Ushûl al-Nahw64

Sedangkan karya-karya Shâthibî yang telah diterbitkan adalah :

57 Harif Susmana, Op. cit, hlm. 108.

58 Beliau adalah seorang tokoh yang álim dalam berbagai disiplin keilmuan, baik ilmu pengetahuan tradisional maupun rasional. Bahkan diantara sarjana Barat menempatkan dirinya setingkat mujtahid. Begitu tingginya ketenaran al-Tilimsânî ini sehingga pada waktu wafatnya, Ibnu Arafah (w. 803 H/ 1400 M) meratapi kepergiannya sebagai kematian ilmu pengetahuan rasional. Lihat, M. Khalid Mas'ud, Op. cit, hlm. 112

59 Granada merupakan ibukota kerajaan Banû Nas\}r, yang terletak di utara Sierranadeva. Dikelilingi sungai Genil, sungai El Derro dan padang rumput La Vega. Lihat, M. Khalid Mas'ud, Ibid hlm, 87-88.

60 Ibid, 111

61 Ahmad 'Abd al-Shâfî dalam Abû al-Ishâq Ibrâhîm bin Mûsâ bin Muhammad alLakhmî al-Shâthibî, hlm. 8-9.

62 Ibid.

${ }^{63}$ Ahmad al-Raisûnî, hlm. 111.

${ }^{64}$ Ibid., hlm. 114-115

372 JURNAL LISAN AL-HAL 
a. Al-Muwâfaqât fi Ushûl al-Ahkâm. Karya ini merupakan magnum opusnya al-Shâthibî yang banyak dijadikan referensi dan dipergunakan secara luas oleh para sarjana modern ${ }^{65}$.

b. Al-I'tishâm, terdiri dari dua juz. Dalam kitab ini al-Shâthibî secara khusus mencanangkan untuk mendiskusikan problematika bid'ah. Di dalamnya juga dijelaskan perbedaan antara bid'ah, maslahah almursalah dan al-istihsân. Melihat dari isi dan gaya penyampaiannya jelas bahwa kitab itu ditulis untuk meluruskan bid'ah yang nampaknya begitu menggejala di masanya. ${ }^{66}$

c. Al-Ifâdât wa al-Irshâdât, merupakan koleksi al-Shâthibî tentang catatan-catatan dan diskusi-diskusi kelas. ${ }^{67}$

Sebagai salah satu pengikut setia Imam Mâlik, al-Shâthibî berpendapat bahwa kebiasaan yang tidak bertentangan dengan nash, dapat diadopsi sebagai yang include dalam sistem hukum mereka. Tetapi, dalam membincang tentang kebiasaan, Al-Shâthibî tidak memakai term 'urf sebagaimana layaknya ulama-ulama ushûl al-fiqh lainnya. Dia lebih memilih istilah 'âdât atau 'awâíd sebagai kata plural dari kata 'âdah"8, dari pada istilah 'urf. Tetapi term 'âdah menurut Al-Shâthibî ternyata mempunyai pengertian yang tidak berbeda dengan 'urf. Istilah 'âdah dan 'urf hanya berbeda secara lafzhiyyah semata; al-khulf lafzhiyyun. ${ }^{69}$ Al-

65 Abû al-A'lâ al-Maudûdî dalam upaya mengenalkan hukum Islam di Pakistan, telah merekomendasikan penerjemahan kitab al-Muwâfaqât ke dalam bahasa-bahasa nasional. Apa yang diharapkan dari upaya tersebut adalah para ahli hukum bisa memperoleh pandangan yang mendalam dan pemahaman yang benar tentang ruh fiqh (hukum Islam). Lihat, M. Khalid Mas'ud, hlm. 195-196.

66 Adalah Rashîd Ridhâ yang memberikan kesan tersebut. Oleh karenanya, dia banyak mereferensi al-Shâthibî dalam usahanya memberantas bid'ah. Hal ini dibuktikannya dengan mempublikasikan ide al-Shâthibî tentang bid'ah dalam kitabnya alManar. Kemudian pada tahun 1913-1914 M dia mengedit dan mempublikasikan kitab alI'tishâm. Lihat, M. Khalid Mas'ud, Op. cit, hlm. 199.

${ }^{67}$ M. Khalid Mas'ud, Op. cit, hlm. 120-122.

${ }^{68}$ Penggunaan kata 'âdât dan 'awâid oleh al-Shât\}ibî rupanya memiliki indikasi tertentu. Kata 'âdât digunakan untuk kasus-kasus hukum yang berlawanan dengan ibadah. Sedangkan 'awâid dipakai al-Shât\}ibî untuk menunjukkan perilaku dan kebiasaan manusia. Meskipun penempatan kedua istilah tersebut tidak dilakukan secara konsisten. Periksa, Abû al-Ishâq Ibrâhîm bin Mûsâ bin Muhammad al-Lakhmî al-Shâthibî, Ibid, Vol. II, hlm. 200-211.

${ }^{69}$ Hal ini ditunjukkan oleh komentar Muhammad al-Khadhr Husain al-Tûnisî -selaku komentator kitab al-Muwâfaqât fî Ushûl al-Ahkâm--, bahwa dalam memberikan catatan dalam kitab tersebut-terutama dalam bab 'Awâ'id-dia lebih menggunakan istilah 'urf dari pada 'âdah. Penggunaan istilah yang berbeda tersebut mengindikasikan bahwa kedua istilah 'urf dan áddah memiliki kesamaan makna, yaitu kebiasaan sebuah komunitas masyarakat. Lebih jelasnya, baca Abû al-Ish\}âq Ibrâhîm bin Mûsâ bin 
Shâthibî memaknai 'âdah dengan perbuatan-perbuatan tertentu, apabila diandaikan perbuatan tersebut terjadi tanpa halangan maka perbuatan tersebut tidak akan terjadi, kecuali dengan cara tertentu yang diketahui melalui perbuatan lain yang sepadan. ${ }^{70}$

Definisi ini agaknya cukup rumit dipahami, karena pengertian tersebut berangkat dari hal-hal yang tidak wajar (kharq al-'âdah). Namun secara simplistis, istilah 'âdah menurut Al-Shât\}ibî diarahkan pada kebiasaan (habits and customs) dan tingkah laku manusia. Seperti makan, minum, kebahagiaan, tidur, cara berpakaian, berkarakter keras dan sebagainya merupakan ilustrasi 'âdah yang ditampilkan Al-Shât\}ibî71. Istilah 'âdah juga dihadapkan pada kata 'ibâdah'2, yang kemudian di dalam kitab-kitab fiqh dikenal dengan istilah mu'âmalah (interaksi antar sesama manusia). Bahwa ada dua macam yang dikehendaki oleh shara', pertama, kebiasaan yang telah berlangsung lumrah dalam sebuah komunitas masyarakat, misalnya dalam berbagai bentuk usaha dan kegiatan keduniaan yang sudah menjadi satu cara tertentu untuk mewujudkan keinginannya. Hak ini bisa berbentuk transaksi dalam segala jenisnya dan penditribusian harta dengan segala macamnya. Kedua, ibadah yang wajib bagi orang mukallaf dari aspek ketundukannya pada Dhat Yang Maha Esa. ${ }^{73}$

Hikmah yang diambil dari pembagian ini adalah ketika satu kebiasaan tertentu pada seorang mukallaf, maka dia tidak menerima perubahan apapun. Demikian sebaliknya, kebiasaan yang tidak tertentu pada mukallaf akan mengalami perubahan. Dan hal ini tidak butuh pada dalil, oleh sebab persoalannya sudah jelas. Dengan begitu, dalam pandangan al-Shât\}ibî, ada dua sharat keberlakuan 'âdah yaitu 1) Istiqrâr (ketetapan), bahwa kebiasaan yang terjadi dalam alam nyata mnerupakan sesuatu yang sudah diketahui (ma'lûm) bukan sesuatu yang masih menjadi

Muhammad al-Lakhmî al-Shâthibî, Op cit, Vol. II, hlm. 199-201.

70 Ibid, hlm. 195.

71 Ibid, hlm. 208-209.

72 Ibid, hlm. 211. Perkara-perkara yang dishari'atkan oleh al-Shâthibî dibagi kepada ibadah dan 'âdah. Dan keduanya mempunyai wilayah yang berbeda. Hal ini bisa dilihat ketika al-Shâthibî membahas tentang bid'ah, apakah mencakup ranah 'âdah ataukah hanya tertentu pada ibadah saja ?. Lebih jelasnya baca, Abû al-Ishâq Ibrâhîm bin Mûsâ bin Muhammad al-Lakhmî al-Shâthibî, al-I'tishâm, Vol. II, (Beirut : Dâr al-Kutub al-'Ilmiyyah, 1995), hlm. 73-75.

73 Abû al-Ishâq Ibrâhîm bin Mûsâ bin Muhammad al-Lakhmî al-Shâthibî, alMuwâfaqât...., Vol. II, hlm. 158.

$374 \mid$ JURNAL LISAN AL-HAL 
praduga. 2) Istimrâr (kontinuitas), bahwa kebiasaan tersebut berlaku secara terus menerus, bukan sementara. ${ }^{74}$ Hal ini dibuktikan dengan beberapa hal75, yaitu :

a. Bahwa berdasarkan penelitian (istiqrâ'), sharî'iah dicanangkan karena adanya ketetapan dan kontinuitas tersebut. Bahwa pembebanan universal (takâlîf kulliyah) yang dinisbatkan pada orang mukallaf adalah ditetapkan dalam timbangan, ukuran dan klasifikasi yang sama. Tidak ada perbedaan yang didasarkan pada tempo dulu, sekarang dan masa mendatang. Sementara perbuatan mukallaf sebagai obyek taklîf hanya akan berlaku menurut klasifikasinya. Jika kebiasaan-kebiasaan dalam dunia nyata ini berbeda, niscaya hal itu akan menghendaki perbedaan perundang-undangan dan klasifikasi taklîf. Dan hal semacam itu batil adanya.

b. Bahwa berita-berita yang dibawa Shâri' (al-akhbâr al-shar'î) datang sesuai dengan kenyataan yang ada. Oleh sebab itu, berita tersebut selamanya tidak akan berubah. Seperti, kabar tentang langit, bumi, halhal yang berada diantara langit dan bumi, serta segala sesuatu yang berlaku di langit dan bumi berupa segala kemanfaatan, perubahan dan keadaan. Dan apa yang telah digariskan oleh Allah (sunnatullâh) itu tidak akan pernah berubah. Demikian juga makhluk-Nya. Sebagaimana sharî'ah juga akan tetap selamanya.

c. Andaikan keberlangsungan kebiasaan tidak diketahui, niscaya agama tidak akan diketahui dari asalnya. Lebih-lebih untuk mengetahui cabang-cabangnya. Hal itu disebabkan bahwa agama hanya bisa diketahui setelah mengenal kenabian (al-nubuwwah). Jalannya tiada lain adalah dengan perantaraan mukjizat, yakni perbuatan yang menyimpang dari kebiasaan (khâriq li al-'âdah). Dan sebuah perbuatan dianggap menyimpang dari kebiasaan kalau keberlakuan kebiasaan tersebut sudah pasti, baik untuk masa sekarang maupun masa mendatang, sebagaimana yang telah terjadi pada masa lampau.

Hanya saja, konsep kontinuitas 'âdah al-Shâthibî ini dipersoalkan dalam dua hal ${ }^{76}$; Pertama, bahwa kontinuitas sesuatu di dunia ini adalah sama dengan permulaan keberadaannya. Karena untuk kontinuitasnya dia butuh pelaku yang mungkin tidak ditemukan. Sebagaimana pada periode awal, kontinuitas tidak ada dalam kenyataan itu adalah mungkin. Ketika dia ditemukan, maka satu dari dua kemungkinan itu akan tercapai, yaitu

74 Ibid, hlm. 194.

75 Ibid, hlm. 194-195.

${ }^{76}$ Ibid, hlm. 195-196. 
eksistensinya. Atau dia tetap dalam ketiadaannya. Kalau ada kemungkinan tidak adanya kontinuitas pada sesuatu, bagaimana mungkin seseorang bisa mengetahui kontinuitasnya. Kedua, bahwa seringkali terjadi peristiwa yang menyimpang dari kebiasaan (khawâriq al-'Âdât)77, terutama yang terjadi pada para nabi, auliyâ' (kekasih Allah) dan umat-umat terdahulu yang punya kebiasaan berbeda. Kenyataan ini semakin menguatkan alasan tidak adanya kontinuitas tersebut. Maka, keberlakukan 'âdah itu tidak bisa diketahui secara pasti.

Terhadap persoalan ini, al-Shât\}ibî secara cerdas menjawab satu persatu. Pertama, bahwa kemungkinan secara rasional (al-jawâz al-'aqlî) tidak akan tertolak secara akal. Hanya tradisi yang pasti (al-sam' al-qath'î) yang bisa menolaknya. Sementara berdasarkan tradisi kita ketahui adanya kemungkinan kontinuitas tersebut. Kemungkinan tidak adanya kontinuitas yang dipersoalkan diatas tidak bertentangan dengan posisi tradisi. Karena pengertian kemungkinan itu bersifat rasional, sedangkan tradisi tidak membicarakan kemungkinan, tetapi lebih merujuk pada kenyataannya (al-wuqû'). Dan tidak sedikit hal-hal yang bisa saja terjadi, tapi tidak pernah terjadi. Demikian pula, alam ini sebelum adanya, ada dua kemungkinan; tetap pada asalnya yaitu tidak ada atau diwujudkan dalam kenyataan. Penisbatan kontinuitas tidak ada atau malah diwujudkan, dalam dunia nyata dari segi kontinuitas itu sendiri adalah satu nisbat. Oleh sebab itu, istilah kemungkinan itu menunjukkan kepada yang mungkin itu sendiri. Sementara keniscayaan (wujûb) dan mustahil (imtinấ) lebih menunjukkan faktor eksternal (amr khârijî). Maka, keduanya tidak bertentangan.

Kedua, bahwa pengetahuan yang didasarkan pada kebiasaan hanya berlaku pada hal-hal yang universal (kulliyât al-wujûd) bukan hal-hal yang parsial (juz'iyyat). Oleh sebab itu, jika terdapat sesuatu yang parsial menyimpang maka hal itu tidak menolak yang universal. Andaikan

77 Ketika terdapat suatu peristiwa terjadi bertentangan dengan kebiasaan yang lumrah terjadi, maka kejadian itu dikenal dengan istilah khâriqah al-áddah. Terkait dengan hal ini, al-Shâthibî menegaskan bahwa kita tidak bisa menghukumi -baik menolak ataupun menerima-- segala sesuatu yang terjadi di luar kebiasaan kecuali setelah dihadapkan pada hukum-hukum sharîáh. Kalau sharîáh memperkenankan, maka kebiasaan yang tidak lumrah tersebut benar dan bisa diterima. Sebaliknya, jika tidak dapat legitimasi dari Shâri' tentu kebiasaan tersebut tidak bisa dibenarkan. Namun, alShât\}ibî mengecualikan peristiwa-peristiwa aneh yang dialami oleh para nabi. Hal itu lebih disebabkan bahwa peristiwa tersebut mesti benar adanya, meskipun tidak bisa dinalar oleh siapapun. Contohnya, Nabi Ibrâhîm mau menyembelih putera kesayangannya, Ismâ'îl karena semata-mata berdasarkan mimpi. Ibid, hlm. 194.

376 JURNAL LISAN AL-HAL 
kontinuitas pengetahuan tentang kebiasaan tidak ada, niscaya terjadinya hal-hal yang menyimpang itu tidak mungkin teridentifikasi. Karena itulah, sebetulnya, terjadinya peristiwa yang menyimpang dari kebiasaan itulah yang menjamin kebiasaan yang universal. Dan tentu, hal ini menuntut adanya kontinuitas. ${ }^{78}$

Jawaban yang dilontarkan al-Shâthibî ini menunjukkan bahwa kontinuitas hanya terdapat pada kebiasaan-kebiasaan yang bersifat universal. Hal ini yang kemudian dikenal dengan al-áwâid al-mustamirrah. Al-Shâthibî membagi al-áwâid al-mustamirrah kepada dua macam, yaitu :

a. al-'Awâid al-Shar'iyyah, yaitu kebiasaan-kebiasaan yang diakui atau ditolak secara tegas oleh dalil shar'î. Hal ini berupa perintah dari shara' -baik berbentuk kewajiban atau anjuran-atau shara' melarangnya dalam bentuk ketidaksukaan (karâhah) dan keharaman atau bahkan shara' mempersilahkan untuk dilakukan atau ditinggalkan, yang dikenal dengan jawâz. ${ }^{79}$

b. al-'Awâid al-Jâriyah, sejumlah kebiasaan yang berlaku dalam komunitas masyarakat, yang sengaja didiamkan oleh shara', tidak diterima dan juga tidak ditolak. Kebiasaan jenis kedua ini adakalanya tetap seperti adanya nafsu makan, minum, bersetubuh, melihat dan sebagainya. ${ }^{80}$

Di bagian yang lain, Al-Shâthibî juga membagi 'awâid pada dua macam dari segi terwujudnya dalam kenyataan, ${ }^{81}$ yaitu :

a. Al-'Awâid al-Ámmah, yakni kebiasaan yang tidak akan berubah dalam ruang, waktu dan keadaan. Seperti makan, minum, kebahagiaan, kesedihan, tidur, bangun, memperoleh hal-hal yang baik dan diinginkan, dan sebagainya. Maka, kebiasaan ini akan kekal sampai akhir hayat. Inilah 'âdah yang membuktikan bahwa kebiasaan itu merupakan sesuatu yang diketahui (ma'lûmah), bukan hal yang masih praduga (mazhnûnah).

b. Kebiasaan yang berbeda seiring dengan perbedaan ruang, waktu dan keadaan. Misalnya, bentuk pakaian, tempat tinggal, cepat atau lambat dalam bertindak dan semisalnya. Kebiasaan-kebiasaan seperti ini akan berubah sesuai dengan perubahan tempat, waktu dan kondisi yang melingkupinya.

Paparan yang ditampilkan al-Shâthibî ini mengindikasikan bahwa hukum yang bisa menerima perubahan adalah hukum yang didasarkan

78 Ibid, hlm. 196-197.

${ }^{79}$ Ibid, hlm. 197-198.

80 Ibid, hlm. 198-199.

81 Ibid, hlm. 208-209. 
pada kebiasaan masyarakat tertentu, kecuali dalam kebiasaan tersebut terkandung ketaatan ( $t a^{\prime} a b b u d$ ). Dalam arti, bahwa setiap kebiasaan yang telah digariskan secara tegas oleh nash, maka dalam tataran aplikasinya mau tidak mau harus tunduk di bawah kata teks. Ini yang disebut dengan al-'awâid al-shar'iyyah. Oleh sebab itu, perubahan hukum hanya berlaku pada al-'awâid al-jâriyyah bain al-nâs, bahwa kebiasaan-kebiasaan yang berlaku umum di kalangan masyarakat akan mengalami perubahan berkelindan seiring dengan pergeseran waktu dan keadaan sosiokulturalnya. Dan semua itu, mendapat legitimasi dari Shâri' selama tidak keluar dari rel inti ajaran sharî'at, yakni terciptanya kemaslahatan umat dan menghilangkan kerusakan (jalb al-mashâlih wa dar-u al-mafâsid).

\section{Implementasi 'Urf dalam Pembentukan Hukum Islam}

Ada dua cara pandang dalam rangka menjawab persoalan ini ${ }^{82}$; Pertama, menyatakan bahwa hukum Islam merupakan hukum suci par excellence, sempurna, dan abadi. Oleh karenanya, tidak bisa beradaptasi dengan perubahan. Kedua, bahwa hukum Islam bisa beradaptasi dengan perubahan. Hal ini dibuktikan bahwa prinsip-prinsip hukum mengacu pada kemaslahatan, fleksibelitas hukum Islam dalam tataran aplikatif dan penekanan pada ijtihâd yang dilakukan oleh para imam madhhab dalam memberikan jawaban terhadap setiap persoalan yang dihadapinya.

Dalam hal ini, rupanya al-Shâthibî menganut cara pandang yang kedua, bahwa hukum dapat berubah seiring pergantian waktu, perbedaan tempat dan keadaan. Namun, hukum yang dapat berubah hanyalah hukum-hukum yang memang terbangun di atas pondasi kebiasaan ('urf). Hal ini berdasarkan atas kaidah yang mashhûr di kalangan ulama, yakni :

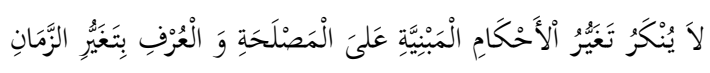

"Perubahan hukum yang didasarkan pada kemaslahatan dan 'urf/adat akan berkelindan dengan peralihan waktu adalah sesuatu yang tidak perlu diingkari“.83

82 M. Khalid Mas'ud, Islamic Legal Philosofy; a Study of Abu Ishaq al-Shatibi's, Life and Thought, terj. Yudian W. Asmin, (Surabaya : al-Ikhlas, 1995), hlm. 23-24.

83 'Alî Ahmad al-Nadawî, al-Qawâ'id al-Fiqhiyyât; Mafhûmuhâ wa Nash-atuhâ wa Tathawwuruhâ wa Dirâsât Muallifâtihâ wa Adillatuhâ wa Muhimmâtuhâ wa Tathbîquhâ, (Damaskus : Dâr al-Qalam, 1994), hlm. 158. Bandingkan dengan kaidah lain, lâ yunkaru taghayyur al-Ah\}kâm bi taghayyur al-azmân, perubahan hukum yang seiring dengan perubahan masa adalah sesuatu yang tidak bisa dipungkiri. Lihat, 'Abd al-Karîm Zaydân, al-Wajîz fì Ushûl al-Fiqh, (Beirut : Muassasah al-Risâlah, 2001), hlm. 258.

$378 \mid$ JURNAL LISAN AL-HAL 
Al-Shâthibî menegaskan bahwa perubahan hukum yang didasarkan pada perubahan kebiasaan pada hakikatnya bukan disebabkan perbedaan khithâb dari shâri'. Karena sejatinya, shara' diancang untuk selamanya. Andaikata dunia akan dikekalkan tanpa batas, maka tidak akan ada penambahan taklîf dari shâri'. Perbedaan yang dimaksud adalah bahwa setiap kebiasaan yang berbeda tersebut dikembalikan kepada dasar shar'î yang kemudian memberikan keputusan hukumnya. ${ }^{84}$

Hukum-hukum yang bisa berubah hanyalah hukum ijtihâdiyyah yang dihasilkan dari dalil-dalil zhanniyyah -bukan hukum yang ditunjukkan dalil qath'iyyah-yang didasarkan pada nilai-nilai kemaslahatan atau kebiasaan. Al-Shâthibî mengajukan lima jenis perubahan dan perbedaan, yaitu perubahan nilai-nilai sosial, perbedaan dalam mengungkapkan sebuah kehendak, perbedaan perbuatan dalam mu'âmalah (interaksi antar sesama manusia), perbedaan yang terjadi karena faktor-faktor eksternal dari orang mukallaf, dan perubahan yang disebabkan kelainan diri dan sudah menjadi satu kebiasaan. ${ }^{85}$ Namun demikian, kelima jenis perubahan dan perbedaan tersebut lebih disebabkan oleh dua faktor utama ${ }^{86}$; Pertama, kerusakan zaman dan pergeseran nilai. Contohnya kebiasaan pengurus masjid mengunci pintupintu masjid diluar waktu shalât. Pada awalnya, mengunci pintu masjid yang bisa menghalangi seseorang untuk melaksanakan ibadah (shalât dan I'tikâf) adalah tidak diperkenankan. Sebab sejatinya, masjid adalah tempat ibadah umum yang karenanya tidak layak dikunci. Namun demi menjaga barang-barang masjid dari tangan-tangan jahil, maka hukum mengunci pintu masjid itu kemudian diperbolehkan, bahkan dianjurkan.

Kedua, disebabkan oleh perubahan kebiasaan dan perkembangan zaman. Seperti kodifikasi al-Qurân yang pada masa Nabi SAW. hanya ditulis di daun-daun lontar, pelepah kurma, dan tulang-belulang. Pada masa-masa selanjutnya, kalâm llâhî itu kemudian ditulis dalam kertas permanen yang pada akhirnya dikenal dengan nama mushhaf. ${ }^{87}$ Tetapi, dalam hal ini al-Shâthibî mengecualikan kebiasaan para Nabi. Walaupun perbuatan dan perkataan para Nabi itu tidak wajar dalam pandangan

84 Abû al-Ishâq Ibrâhîm bin Mûsâ bin Muhammad al-Lakhmî al-Shâthibî, alMuwâfaqât fî Ushûl al-Ahkâm, Vol. II, (Beirut: Dâr al-Fikr, tt), hlm. 198-199.

85 Abû al-Ishâq Ibrâhîm bin Mûsâ bin Muhammad al-Lakhmî al-Shâthibî, Op. Cit., hlm. 198-199.

${ }^{86}$ Muhammad Shidqî bin Ahmad al-Burnû, Op. Cit., hlm. 183. Bandingkan dengan Ibrâhîm Muhammad Mahmûd al-Harîrî, al-Madkhal ilâ al-Qawấid al-Fiqhiyyah alKulliyyah, (Amman: Dâr 'Imâr, 1998), hlm. 115-116.

87 Ibid., hlm. 183-185. 
orang-orang kebanyakan, maka semua itu adalah benar adanya. Karena para Nabi terpelihara (ma'shûm) dari hal-hal yang dilarang. ${ }^{88}$ Walaupun begitu, kebenaran yang ada pada kebiasaan para Nabi yang kontroversial tersebut, bukanlah untuk diteladani. ${ }^{89}$ Akan tetapi, hanya sebagai pembuktian kenabian (al-nubuwwah) yang diberikan kepada dirinya.

Ketika al-Shâthibî menegaskan bahwa kebiasaan-kebiasaan itu diperhitungkan oleh shara' (mu'tabaratun shar'an),90 maka kebiasaan memegang peranan penting dalam dinamika hukum Islam. Hal ini bisa dilihat betapa hukum Islam selalu mendambakan kemaslahatan. Dan yang menjadi parameter terwujudnya kemaslahatan pada kehidupan manusia adalah kebiasaan manusia itu sendiri. Dalam arti, bahwa kebiasaan yang berlangsung dalam komunitas masyarakat tertentu merupakan cerminan dari kemaslahatan. Hal ini didukung dengan konsepnya yang membagi kebiasaan pada dua macam; al-'awâid al-shar'iyyah (kebiasaan yang ditegaskan oleh shara') dan al-'awâid al-jâriyah bain al-nâs (kebiasaan yang sudah berlaku umum di masyarakat). Dan kebiasaan macam yang kedua ini, adakalanya yang tidak berubah dan adakalanya berubah. Kelima jenis perubahan yang diajukan al-Shât\}ibi -sebagaimana yang dipaparkan pada bahasan sebelumnya-semakin menguatkan bahwa perubahan 'urf atau kebiasaan adalah berperan dalam membuat dinamika hukum Islam. Hal ini lebih disebabkan bahwa perubahan itu, diterima dan diamini oleh sharî‘ah. ${ }^{91}$

Karena fokus perhatian tulisan ini adalah pada aspek pembentukan hukum Islam dalam menghadapi perubahan kebiasaan dalam konteks kekinian, maka sampel integrasi hukum Islam dengan perubahan 'urf akan dikemukakan di bawah ini. Penulis hanya mengambil dua sampel yang dijumpai dalam praktek keseharian; satu sampel dalam ranah transaksi yang menampilkan aturan tentang salam (akad pesanan) dan satu contoh yang berkaitan dengan perkawinan, yaitu tentang ta'lîq thalâq (mengkaitkan perceraian).

a. Salam (akad pesanan)

Secara sederhana, salam berarti pembelian barang yang diserahkan di kemudian hari dan sudah ditentukan sebelumnya, sedangkan pembayarannya dilakukan di muka. ${ }^{92}$ Pada dasarnya, transaksi demikian

88 Ibid, hlm. 194.

${ }^{89}$ Ibid, hlm. 205.

90 Ibid, hlm. 200-201.

91 Ibid, hlm. 197-199.

92 Muhammad ibn Ahmad ibn Muhammad Ibn Rushd, Bidâyat al-Mujtahid wa $380 \mid$ JURNAL LISAN AL-HAL 
tidak sejalan dengan prinsip umum dalam bertransaksi, karena termasuk bai' al-ma'dûm (tukar menukar barang yang tidak ada) yang dilarang. Akan tetapi, Rasûlullah melegalisirnya karena transaksi tersebut sudah menjadi tradisi masyarakat Medinah. Beliau bersabda :

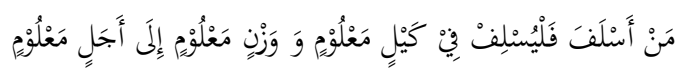

"Barang siapa yang melakukan akad salam, hendaknya dia melakukannya dengan takaran yang jelas dan timbangan yang jelas pula, untuk jangka waktu yang telah disepakati".93

Dalam konsep fiqh klasik dinyatakan bahwa salah satu sharat barang-barang yang boleh dipesan adalah tidak boleh berupa makanan yang dimasak dengan menggunakan api, seperti roti, goreng-gorengan dan masakan yang direbus dan dibakar atau dipanggang.94 Alasan yang diajukan adalah karena makanan yang dimasak sulit untuk diidentifikasi satuan-satuannya dan ukurannya. Oleh karena itu, kesulitan tersebut akan berpengaruh pada klasifikasi kualitas barang yang dipesan.

Penerapan konsep ini pada masa sekarang perlu kajian ulang. Karena penerapan secara apa adanya, akan menimbulkan kesulitan di tingkat penerapannya. Hal mana dibuktikan bahwa kita seringkali mendapatkan kebiasaan yang cukup populer dalam masyarakat -terutama ketika mengadakan satu acara resepsi atau hajatan-yang terbiasa memesan satu paket makanan dan minuman dari sebuah rumah makan, restoran atau warung kecil. Bahwa pemesanan barang tentu sudah

Nihâyat al-Muqtashid, Vol. II, (Beirut: Dâr al-Jîl, 1989), hlm. 327. Kalangan Shâfî'iyah mendefinisikan salam sebagai sebuah transaksi dengan menggunakan lafazh salam atau salaf atas satu barang yang disifati dalam tanggungan dengan pembayaran/ganti di muka. Lihat, Taqiyyuddîn Abû Bakr bin Muhammad al-Husainî, Kifâyat al-Akhyâr fî Hall Ghâyat al-Ikhtishâr, Vol. I, (Beirut: Dâr al-Fikr, 1994), hlm. 208 dan Ahmad bin 'Umar al-Shâthirî, al-Yâqût al-Nafîs fî Madhhab Ibn Idrîs, (Beirut: Dâr al-Thaqâfah al-Islâmiyyah, tt), hlm. 81.

${ }^{93}$ Abû 'Îsâ Muhammad ibn 'Îsâ ibn Saurah, Sunan al-Turmudhî, Vol. III, (Beirut : Dâr al-Fikr, 1994), hlm. 54.

94 Ada lima sharat yang diberikan kepada barang yang dipesan (muslam fîh); 1) Spesifik, ditentukan dengan sifat tertentu, 2) berupa satu jenis tertentu yang tak bercampur dengan lainnya dan pembuatannya tidak boleh menggunakan api, 3) harus berupa hutang, 4) tidak boleh memesan barang yang sudah ada dan tertentu 5) berupa barang yang sah diperjualbelikan. Hanya saja, sharat yang kedua merupakan pendapat imam Abû Hanîfah dan al-Shâfi'î. Sementara imam Mâlik memperkenankannya. Lihat, Ibrâhîm al-Bâjûrî, H\}âshiyah al-Bâjûrî 'alâ Ibn Qâsim al-Ghazî, Vol. I, (Semarang: Toha Putra, tt), hlm. 353-356, Muhammad al-Sharbînî al-Khathîb, Al-Iqnâ' fî Hall Alfâzh Abî Shujâ', Vol. II, (Semarang: Toha Putra, tt), hlm. 18-20 dan Abû al-Mawâhib Ábd. AlWahhâb bin Ahmad bin Álî al-Anshârî al-Sha'rânî, Al-Mîzân al-Kubrâ, Vol. II, (Surabaya: alHidayah, tt), hlm. 73. 
dipertimbangkan terlebih dahulu oleh pemesan (muslim) tentang klasifikasi kualitas barang, dengan melihat kebiasaan kualitas barang pada masing-masing pihak yang menerima pesanan (muslam ilaih). Oleh sebab itu, pemesanan makanan -yang sudah pasti pembuatannya menggunakan api atau arus listrik-dapat dibenarkan ${ }^{95}$. Penerimaan terhadap kebiasaan yang sudah lumrah terjadi di masyarakat dalam memesan makanan tersebut lebih didasarkan pada bahwa kebiasaan ini berada ranah muámmalah. Dan al-Shâthibî menegaskan kebiasaan perbuatan dalam mu'amalah mendapatkan legitimasi dari shâri'.

b. Ta'lîq thalâq.

Dalam Muktamar Nahdlatul Ulama ke-3 di Surabaya, diputuskan bahwa hukumnya ta'lîq al-thalâq (menggantungkan perceraian) adalah makrûh dan sah. Dalam arti, bila pernyataan itu dilanggar oleh pihak suami, maka akan jatuh talak. ${ }^{96}$ Sebetulnya, para yuris Islam telah lama memperdebatkan; sejauh mana perceraian yang dikaitkan dengan persyaratan tertentu dapat dianggap sah guna melepaskan tali ikatan pernikahan. ${ }^{97}$ Ibnu Hazm misalnya, berpendapat bahwa semua bentuk ta'lîq thalâq tidaklah valid dan tidak akan mempengaruhi status perkawinan. Alasan yang diajukan adalah karena ta'liq thalâq tidak diatur oleh nash al-Qurân ataupun al-Hadîth.98 Sementara, mayoritas cendikiawan muslim lainnya menegaskan bahwa perceraian yang digantungkan, baik dalam bentuk ta'lîq qasamî (dilakukan melalui sumpah) ataupun ta'lîq sharthî (dikaitkan dengan sharat-sharat tertentu), adalah valid untuk mengakhiri tali ikatan perkawinan. ${ }^{99}$

Di Indonesia, merupakan hal yang lumrah dan biasa pada saat melakukan akad nikah, sang suami mengucapkan ta'lîq thalâq. Dia mengajukan sharat bahwa jika dia mengabaikan kewajibannya, menyakiti istrinya atau tidak menghiraukannya dalam jangka waktu tertentu, maka

${ }^{95}$ Hal ini dibenarkan oleh Abû 'Isa, sebagaimana disitir oleh Ibn Saurah, bahwa para ulama memperbolehkan memesan makanan, pakaian dan sebagainya yang kualitas barangnya sudah teridentifikasi. Lihat, Abû 'Îsâ Muhammad ibn 'Îsâ ibn Saurah, Op. Cit., hlm. 55.

96 M. Imam Ghazali Saíd dan A. Ma'ruf Asrori (ed.), Ah\}kâm al-Fuqahâ'; Solusi Problematika Aktual Hukum Islam, Keputusan Muktamar, Munas, dan Konbes Nahdlatul Ulama (1926 M.- 1999 M), (Surabaya: LTN NU Jawa Timur bekerjasama dengan Diantama, 2004), hlm. 40.

97 Muhammad ibn Ah\}mad ibn Muhammad Ibn Rushd, Op. Cit, Vol. II, hlm. 69-70, Sayyid Shabiq, Fiqh al-Sunnah, Vol.III, (Kairo: Dâr al-Kitâb al-Árabî, 1984), hlm. 55-57.

98 Ibid, hlm. 55.

99 Ibid, hlm. 56-57.

$382 \mid$ JURNAL LISAN AL-HAL 
pengaduan istri ke pengadilan agama dengan imbalan uang sepuluh ribu rupiah akan menyebabkan jatuh talak pada si istri. ${ }^{100}$ Ta'lîq thalâq ini diucapkan suami pada setiap pernikahan setelah penandatanganan kontrak perkawinan itu dilaksanakan.

Ta'lîq thalâq ini ditetapkan oleh pemerintah dalam upaya melindungi si istri atas perlakuan yang tidak wajar dari pihak suami. Anggapan bahwa kekuasaan rumah tangga sepenuhnya berada di tangan suami menyebabkan para suami bisa melakukan apa saja sesuai dengan kemauannya sendiri. Tindakan semena-mena dari pihak suami berupa pemukulan, penganiayaan, dan pelecehan fisik seringkali didasarkan bahwa istri harus mengabdi terhadap suami dan tidak boleh membantah. Tanggung jawab suami pun seringkali diabaikan. Oleh karenanya, Ta'lîq thalâq ini diinstitusikan dalam rangka mewujudkan satu bentuk egalitarian yang diberikan kepada istri. Karena kalau dilihat secara mendetail, sebetulnya ta'lîq thalâq ini serupa dengan bentuk perceraian yang diajukan oleh istri dalam bentuk khulu', yaitu satu bentuk perceraian dengan satu imbalan tertentu dari seorang istri untuk sang suami. ${ }^{101}$

Ta'lîq thalâq hakikatnya hanyalah sebuah perjanjian pernikahan, bukan satu bentuk perceraian dari sang suami. Hal ini guna menghindari adanya perceraian yang seringkali mudah dijatuhkan oleh sang suami. Ta'lîq thalâq yang lebih ditempatkan sebagai bentuk perjanjian pernikahan ini dibuktikan dari adanya fakta dalam KHI (Kompilasi Hukum Islam) bahwa ta'lîq thalâq ini berada di bawah Bab tentang Perjanjian Perkawinan (Pasal VII), bukan di bawah Bab Perceraian (Pasal XVI). Dalam KHI itu dijelaskan bahwa perceraian itu baru akan terjadi jika ada pengaduan yang secara sungguh-sungguh diajukan oleh pihak istri kepada Pengadilan Agama. ${ }^{102}$

Atas dasar inilah, ta'lîq thalâq yang biasa dilakukan di Indonesia tidaklah secara otomatis akan menimbulkan jatuh talak jika suami melanggarnya. Akan tetapi, masih menunggu reaksi dari si istri. Disini akan ditemukan perbedaan; kalau dalam konsep fiqh klasik ta'lîq thalâq diyakini oleh mayoritas ulama sebagai representasi perceraian pada satu kondisi tertentu, tapi dalam konteks ke-Indonesia-an ta'lîq thalâq lebih mengarah pada satu bentuk perjanjian antara suami-istri. Perbedaan

100 Lihat shîghat ta'lîq pada Departemen Agama Republik Indonesia, Buku Nikah Suami/Istri.

101 Taqiyyuddîn Abû Bakr bin Muhammad al-Husainî, Op. Cit, Vol. II, hlm. 64 dan Ahmad bin 'Umar al-Shâtharî, Op. Cit, hlm. 151.

102 Departemen Agama RI, Kompilasi Hukum Islam di Indonesia, (tanpa penerbit dan tahun), hlm. 33. 
semata-mata didasarkan pada perbedaan kebiasaan dalam mengungkapkan sesuatu. Perbedaan tersebut, menurut al-Shâthibî, sah adanya. Dan shâri' juga akan mengakuinya.

\section{Kesimpulan}

Dari beberapa paparan sebelumnya, maka ada beberapa hal yang dapat penulis simpulkan. Pertama, konsep Al-Shât\}ibî tentang 'urf mengarah pada kebiasaan (habits and customs) dan tingkah laku manusia. Ada dua sharat keberlakuan 'urf atau 'âdah, yaitu ketetapan (istiqrâr) dan kontinuitas (istimrâr). Al-Shât\}ibî membagi kebiasaan pada dua macam; 1) al-'awâid al-shar'iyyah, yaitu kebiasaan yang dinyatakan secara tegas oleh nas\}s\} shar'î, 2) al-'awâid al-jâriyyah bain al-nâs, kebiasaan yang terjadi dalam satu komunitas masyarakat dan shara' diam tidak berkomentar. Meskipun begitu, shara' juga melegalisasi keberlakuannya. Dalam arti, hukumpun mengikuti apa kehendak kebiasaan tersebut. Al-Shâthibî juga membagi kebiasaan yang ditinjau dari eksistensinya pada dua macam; 1) al-'awâid al-'âmmah, kebiasaan yang berlaku umum, tidak berubah dalam segala ruang, waktu dan keadaan. 2) Kebiasaan yang berbeda seiring dengan pergeseran ruang, waktu dan keadaan. Istilah 'âdah ini oleh alShâthibî dihadapkan pada kata 'ibâdah. Oleh karena ibadah pada dasarnya adalah ketaatan dan kepatuhan yang total kepada Allah (al-taábbud), maka 'âdah pada dasarnya adalah lebih menekankan esensinya (al-iltifât ilâ alma'ânî). Namun begitu, al-Shâthibî memberikan pengecualian bahwa kebiasaan-kebiasaan yang didalamnya terdapat ketaatan, maka pemberlakuannya harus tunduk di bawah nash.

Kedua, implementasi 'urf al-Shâthibî pada tataran praktis dalam upaya pembentukan hukum islam hanya berlaku pada perbuatan yang tidak bermuatan ketaatan (al-taábbud). Dalam arti bahwa kebiasaan yang lebih berorientasi pada pola hubungan antar manusia (mu'amalah) aturan mainnya diserahkan kepada kebiasaan yang berlaku. Oleh sebab itu, hukumpun akan berkelindan mengikuti perubahan kebiasaan. Implementasi 'urf pada akhirnya akan menghasilkan reaktualisasi hukum Islam. Ada beberapa sampel yang bisa diajukan sebagai bentuk implementasi konsep al-Shâthibî di atas, yaitu 1) Memesan (akad salam) barang dalam bentuk makanan dan minuman. 2) Ta'lîq thalâq yang diucapkan suami dalam resepsi akad nikah bukan satu bentuk perceraian dari pihak suami. Tapi hanya sebagai satu bentuk perjanjian pernikahan antara suami-istri.

$384 \mid$ JURNAL LISAN AL-HAL 


\section{Daftar Pustaka}

'Abd al-Wahhâb Khallâf, Mashâdir al-Tashrî' al-Islâmî fí Mâ Lâ Nashsha fî hi, Kuwait: Dar al-Qalam, 1978.

----------------, 'Ilm Ushûl al-Fiqh, Kuwait : Dâr al-Qalam, 1987.

'Abdullâh 'Abd al-Muhsin al-Turkî, Ushûl Madhhab al-Imâm Ahmad, Dirâsah Ushûliyyah Muqâranah, Riyâdh : Maktabah al-Riyâdh alHadîthah, 1977.

'Abd al-Karîm Zaydân, al-Wajîz fî Ushûl al-Fiqh, Beirut : Muassasah alRisâlah, 2001.

'Alî Ahmad al-Nadawî, al-Qawâ'id al-Fiqhiyyât; Mafhûmuhâ wa Nash-atuhâ wa Tathawwuruhâ wa Dirâsât Muallifâtihâ wa Adillatuhâ wa Muhimmâtuhâ wa Tathbîquhâ, Damaskus : Dâr al-Qalam, 1994.

Abdullâh Ahmed An-Na'îm, Dekonstruksi Syari'ah,Wacana Kebebasan Sipil, Hak Asasi Manusia dan Hubungan Internasional dalam Islam, Jogyakarta : LKiS, 1994.

Abu al-Fadhl Jamâluddîn Muhammad bin Mukarram ibn Manzhûr, Lisân al'Arab, Beirut: Dâr al-Fikr, tt

Abû 'Îsâ Muhammad ibn 'Îsâ ibn Saurah, Sunan al-Turmudhî,Beirut : Dâr alFikr, 1994.

Abû al-Hasan 'Alî ibn Muhammad ibn Habîb al-Mâwardî, al-Ahkâm alSulthâniyyah, Kairo : Mushthafâ al-Bâbî al-Halabî, tt.

Abû al-Ishâq Ibrâhîm bin Mûsâ bin Muhammad al-Lakhmî al-Shâthibî, alMuwâfaqât fî Ushûl al-Ahkâm, Beirut : Dâr al-Fikr, t.t. 1995.

Abû al-Mawâhib Ábd. Al-Wahhâb bin Ahmad bin Álî al-Anshârî al-Sha'rânî, Al-Mîzân al-Kubrâ, Surabaya: al-Hidayah, tt.

Abû Muhammad 'Izz al-Dîn ibn 'Abd. Al-Salâm al-Sulamî, Qawâ'id al-Ahkâm fî Mashâlih al-Anâm, Beirut: Dâr al-Kutub al-Ílmiyyah, tt.

Ahmad al-Raisûnî, Nazhariyat al-Maqâshid 'Inda al-Imâm al-Shât\}ibî Herndon, Virginia : al-Ma'had al-'Âlamî li al-Fikr al-Islâmî, 1995.

Ahmad bin 'Umar al-Shâtharî, al-Yâqût al-Nafîs fî Madhhab Ibn Idrîs, Beirut: Dâr al-Thaqâfah al-Islâmiyyah, tt.

Departemen Pendidikan dan Kebudayaan RI, Kamus Besar Bahasa Indonesia, Jakarta: Balai Pustaka, 1989.

Harif Susmana, Shâthibî, Tokoh Pembaharu yang Terlupakan, (dalam majalah Islamuna, Jakarta, Thn I, No 1, Muharram 1425/Maret 2004.

Ibrâhim al-Bâjûrî, Tahqîq al-Maqâm álâ Kifâyat al-Áwâm, Surabaya: Sahabat Ilmu, tt. 
Khalîl 'Abd al-Karîm, al-Judhûr al-Târîkhiyyah lî al-Sharî'ah al-Islâmiyyah, terj. Kamran Asád, Yogyakarta: LkiS, 2003.

M. Imam Ghazali Saíd dan A. Ma'ruf Asrori (ed.), Ah\}kâm al-Fuqahâ'; Solusi Problematika Aktual Hukum Islam, Keputusan Muktamar, Munas, dan Konbes Nahdlatul Ulama (1926 M.- 1999 M), Surabaya: LTN NU Jawa Timur bekerjasama dengan Diantama, 2004.

M. H. Thabâthabâ'î, Mengungkap Rahasia Al-Quran, Bandung: Mizan, 1987.

M. Hasbi ash-Shiddieqy, Falsafah Hukum Islam, Jakarta: Bulan Bintang, 1993.

M. Khalid Mas'ud, Islamic Legal Philosofy; a Study of Abu Ishaq al-Shatibi's, Life and Thought, terj. Yudian W. Asmin, Surabaya : al-Ikhlas, 1995.

Mohammed Arkoun, Berbagai Pembacaan al-Qurân, Jakarta: INIS, 1995.

Mûsâ Ibrâhîm al-Ibrâhîm, al-Madkhal Ilâ Ushûl al-Fiqh wa Târîkh al-Tashrî̀ al-Islâmî, Amman Yordania: Dâr 'âmmâr, 1989.

Muhammad al-Rûkî, Qawâ'id al-Fiqh al-Islâmî min Khilâl Kitâb al-Ishrâf'alâ Masâil al-Khilâf, Damaskus : Dâr al-Qalam, 1998.

Muhammad al-Sharbînî al-Khathîb, Al-Iqnâ' fî̀ Hall Alfâzh Abî Shujâ', Semarang: Toha Putra, tt.

Muhammad bin Ahmad Abû Sahl Al-Sarkhâshî,Al-Mabsûth, Beirut: Dâr alFikr, tt.

Muhammad Hâshim Kamâlî, Sharî̀ah as Understood by the Classical Jurist, Law Journal, 1\&2, hlm. 1998. Islamic Texts Society, 1991.

Muhammad ibn Ahmad ibn Muhammad Ibn Rushd, Bidâyat al-Mujtahid wa Nihâyat al-Muqtashid, Beirut: Dâr al-jîl, 1989.

Muhammad Shidqî bin Ah\}mad al-Burnû, al-Wajîz fî Îdhahh al-Qawâ'id, Beirut : Muassasah al-Risâlah, 1983.

Musthafâ Ahmad al-Zarqâ', al-Madkhal al-Fiqhiyy al-'Âm, Damaskus: Matba'ah Tharayain, $1968 \mathrm{M} / 1387 \mathrm{H}$

Ratno Lukino, Pergumulan antara Hukum Islam dan Adat di Indonesia, Jakarta : INIS, 1998.

Shauqî Ábduh al-Sâhî, Al-Madkhal li Dirâsah al-Fiqh al-Islâmî, Kairo: alMaktabah al-Nahdhiyyah al-Mishriyyah, 1989.

Taqiyyuddîn Abû Bakr bin Muhammad al-Husainî, Kifâyat al-Akhyâr fî Hall Ghâyat al-Ikhtishâr, Beirut: Dâr al-Fikr, 1994.

Wael B. Hallaq, Sejarah Teori Hukum Islam, Pengantar untuk Usul Fiqh Mazhab Sunni, Jakarta : PT. RajaGrafindo Persada, 2000.

Wahbah al-Zuhailî, Ushûl al-Fiqh al-Islâmî, Damaskus: Dâr al-Fikr, 1406 H/

$386 \mid$ JURNAL LISAN AL-HAL 
$1986 \mathrm{M}$.

Waliyullâh bin 'Abd al-Rahîm al-Dihlawî, Hujjat Allâh al-Bâlighah, Kairo : Dâr al-Turâth, 1185 H.

Yasin Dutton, Asal Mula Hukum Islam; Al-Qur'an, Muwaththa' dan Praktik Madinah, Jogyakarta: Penerbit Islamika, 2003.

Zain al-'Âbidîn bin Ibrâhîm bin Nujaim, al-Ashbâh wa al-Nazhâir 'alâ Madhhab Abî Hanîfah al-Nu'mân, Beirut: Dâr al-Kutub al-'Ilmiyyah, 1993.

Zakariyâ al-Anshâri, Ghâyat al-Wus\}ûl Sharh Lubb al-Ushûl, Semarang: Maktabah Hidayah, tt.

Zakiyuddin Baidhowi dan Mutohharun Jinan (ed.), Agama dan Pluralitas Budaya Lokal, Surakarta: Pusat Studi Budaya dan Perubahan Sosial UM Surakarta, 2003. 
"'Urf dan Pembentukan Hukum Islam Al-Shâtibî"

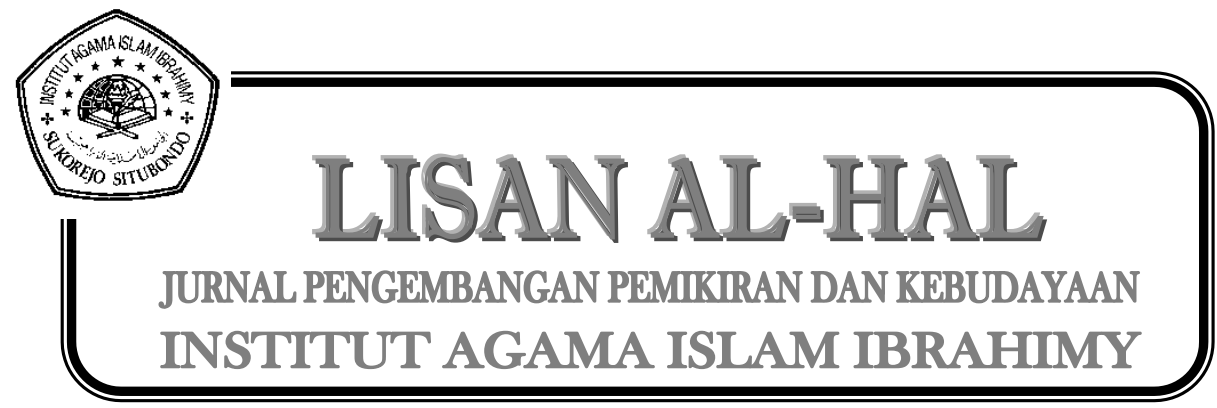

$388 \mid$ JURNAL LISAN AL-HAL 
